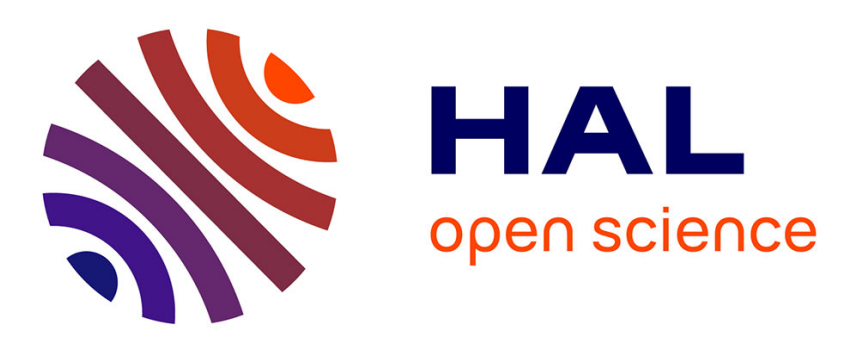

\title{
What do ossification sequences tell us about the origin of extant amphibians?
}

\author{
Michel Laurin, Océane Lapauze, David Marjanović
}

\section{To cite this version:}

Michel Laurin, Océane Lapauze, David Marjanović. What do ossification sequences tell us about the origin of extant amphibians?. Peer Community in Paleontology, 2019, 10.1101/352609 . hal02360950

\section{HAL Id: hal-02360950 https://hal.sorbonne-universite.fr/hal-02360950}

Submitted on 13 Nov 2019

HAL is a multi-disciplinary open access archive for the deposit and dissemination of scientific research documents, whether they are published or not. The documents may come from teaching and research institutions in France or abroad, or from public or private research centers.
L'archive ouverte pluridisciplinaire HAL, est destinée au dépôt et à la diffusion de documents scientifiques de niveau recherche, publiés ou non, émanant des établissements d'enseignement et de recherche français ou étrangers, des laboratoires publics ou privés. 


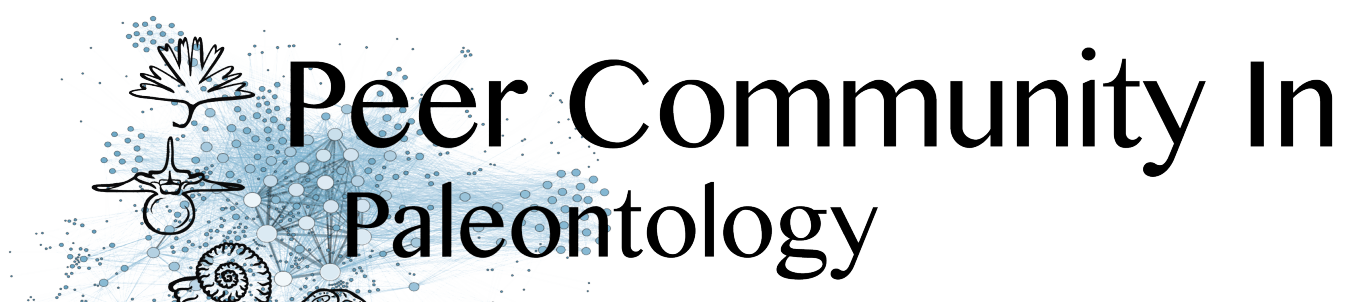

\section{Open Access}

\section{Peer-Reviewed}

\section{RESEARCH ARTICLE}

Cite as: Laurin M, Lapauze $\mathrm{O}$, and Marjanović D (2019). What do ossification sequences tell us about the origin of extant amphibians? bioRxiv 352609, ver. 4 peer-reviewed by PCI Paleo. DoI: 10.1101/352609

Published: 15 October 2019

\section{Recommender:}

Robert J Asher

\section{Reviewers:}

Jennifer Olori and two anonymous reviewers

\section{Correspondence:}

michel.laurin@mnhn.fr

Il. Open Data Open Peer Review

\section{(c) 2019 Author(s)}

\section{(c) (P) CC-BY 4.0}

This work is licensed under the Creative Commons Attribution 4.0 International License.

\section{What do ossification sequences tell us about the origin of extant amphibians?}

\author{
Michel Laurin ${ }^{1}$ D, Océane Lapauze ${ }^{1}$ \& David Marjanović ${ }^{2}$ (D) \\ ${ }^{1}$ CR2P (Centre de Recherche sur la Paléodiversité et les Paléoenvironnements; UMR 7207), CNRS/MNHN/Sorbonne Université, \\ Muséum National d'Histoire Naturelle, Département Histoire de la Terre - Paris, France \\ 2 Museum für Naturkunde (Leibniz Institute for Evolutionary and Biodiversity Research) - Berlin, Germany
}

THIS ARTICLE HAS BEEN PEER-REVIEWED BY PCI PALEO

Read the Editor's recommendation and Referees' reports at DOI:10.24072/pci.paleo.100002

\section{ABStRACt}

The origin of extant amphibians has been studied using several sources of data and methods, including phylogenetic analyses of morphological data, molecular dating, stratigraphic data, and integration of ossification sequence data, but a consensus about their affinities with other Paleozoic tetrapods has failed to emerge. We have compiled five datasets to assess the relative support for six competing hypotheses about the origin of extant amphibians: a monophyletic origin among temnospondyls, a monophyletic origin among lepospondyls, a diphyletic origin among both temnospondyls and lepospondyls, a diphyletic origin among temnospondyls alone, and two variants of a triphyletic origin, in which anurans and urodeles come from different temnospondyl taxa while caecilians come from lepospondyls and are either closer to anurans and urodeles or to amniotes. Our datasets comprise ossification sequences of up to 107 terminal taxa and up to eight cranial bones, and up to 65 terminal taxa and up to seven appendicular bones, respectively. Among extinct taxa, only two or three temnospondyl can be analyzed simultaneously for cranial data, but this is not an insuperable problem because each of the six tested hypotheses implies a different position of temnospondyls and caecilians relative to other sampled taxa. For appendicular data, more extinct taxa can be analyzed, including some lepospondyls and the finned tetrapodomorph Eusthenopteron, in addition to temnospondyls. The data are analyzed through maximum likelihood, and the AICc (corrected Akaike Information Criterion) weights of the six hypotheses allow us to assess their relative support. By an unexpectedly large margin, our analyses of the cranial data support a monophyletic origin among lepospondyls; a monophyletic origin among temnospondyls, the current near-consensus, is a distant second. All other hypotheses are exceedingly unlikely according to our data. Surprisingly, analysis of the appendicular data supports triphyly of extant amphibians within a clade that unites lepospondyls and temnospondyls, contrary to all phylogenies based on molecular data and recent trees based on paleontological data, but this conclusion is not very robust.

Keywords: macroevolution; paleontology; evo-devo; ossification sequences; Lissamphibia; Tetrapoda; phylogeny 


\section{Introduction}

Paleontologists have been studying the origin of the extant amphibian clades for more than a century. Early studies generally proposed an origin of at least some extant amphibians from temnospondyls. Cope (1888) initially suggested that batrachians (anurans and urodeles) derived from temnospondyls (a large clade of limbed vertebrates known from the Early Carboniferous to the Early Cretaceous) because he believed that the batrachian vertebral centrum was an intercentrum, the dominant central element of temnospondyls. Later, Watson (1940) argued that anurans were derived from temnospondyls because of similarities (mostly in the palate) between the temnospondyl "Miobatrachus" (now considered a junior synonym of Amphibamus) and anurans. Monophyly of extant amphibians (Lissamphibia) was proposed by Parsons and Williams (1962, 1963), an idea that was accepted more quickly by herpetologists than by paleontologists. Lissamphibian monophyly was supported by (among a few other character states) the widespread occurrence of pedicellate, bicuspid teeth. The subsequent discovery of such teeth in the amphibamid temnospondyl Doleserpeton (Bolt, 1969) reinforced the widespread acceptance of an origin of Lissamphibia from within temnospondyls (e.g., Schoch and Milner, 2004). Recently, this hypothesis, referred to as the temnospondyl hypothesis or TH for short (Fig. 1c), has been supported by several phylogenetic analyses based on phenotypic data matrices (e.g., Ruta and Coates, 2007; Sigurdsen and Green, 2011; Maddin et al., 2012; Pardo et al., 2017a, fig. S6; Pardo et al., 2017b; Mann et al., 2019).

Other hypotheses about the origin of extant amphibians have been available in the literature for nearly as long a time (see Schoch and Milner, 2004 for a historical review). These were initially formulated especially for the urodeles and caecilians, which are less similar to temnospondyls and lack a tympanic middle ear (which is present in most anurans and often inferred for at least some temnospondyls but absent in lepospondyls). Thus, Steen (1938) highlighted similarities in the palate (broad cultriform process of the parasphenoid) and cheek (loss of several bones) between lysorophian lepospondyls and urodeles. Carroll and Currie (1975) and Carroll and Holmes (1980) argued that the extant amphibians had three distinct origins among early stegocephalians; while they accepted an origin of anurans among temnospondyls, they suggested that urodeles and caecilians originated from two distinct groups of lepospondyls (Rhynchonkos for caecilians, Hapsidopareiidae for urodeles). Later, based mostly on developmental similarities between the temnospondyl Apateon and urodeles, Carroll $(2001,2007)$ and Fröbisch et al. (2007) proposed another hypothesis involving a triphyletic origin of lissamphibians, with an origin of anurans and urodeles from two distinct temnospondyl groups, while the caecilians would remain in the lepospondyl clade. This is what we call the polyphyly hypothesis $(\mathrm{PH})$. We have tested two versions. One (here called PH1; Fig. 1e) was cautiously suggested by Fröbisch et al. (2007); it agrees with the paleontological consensus in placing all or most lepospondyls closer to Amniota than to Temnospondyli (Fig. 1b; Sigurdsen and Green, 2011; Pardo et al., 2017a, fig. S6; Pardo et al., 2017b; Marjanović and Laurin, 2019; Clack et al., 2019; Mann et al., 2019). The other (PH2; Fig. 1f) is modified to make Lissamphibia monophyletic with respect to Amniota, a fact we consider demonstrated beyond reasonable doubt by multiple phylogenetic analyses of molecular data (Fig. 1a; Irisarri et al., 2017; Feng et al., 2017; and references cited therein); this comes at the expense of contradicting the paleontological consensus, which was not yet established when Milner (1993, 16-18, fig. 5B) argued for something like the PH2 as one of two more or less equal possibilities. Anderson (2007) and Anderson et al. (2008) found lissamphibian diphyly, specifically a monophyletic, exclusive Batrachia among the temnospondyls while keeping the caecilians among the lepospondyls (DH1; Fig. 1g). Pardo et al. (2017a, fig. 2, S7) presented a similar hypothesis, with batrachians and caecilians having separate origins within the temnospondyls (DH2; Fig. 1h); we should point out, however, that their dataset contained only temnospondyls and lissamphibians, and while they found the $\mathrm{DH} 2$ using Bayesian inference, it was only one of four equally parsimonious results (see Marjanović and 
bioRxiv preprint first posted online Jun. 20, 2018; doi: http://dx.doi.org/10.1101/352609. The copyright holder for this preprint (which was not peer-reviewed) is the author/funder, who has granted bioRxiv a license to display the preprint in perpetuity.

All rights reserved. No reuse allowed without permission.

$\mathrm{PCI}$

Paleo

a)

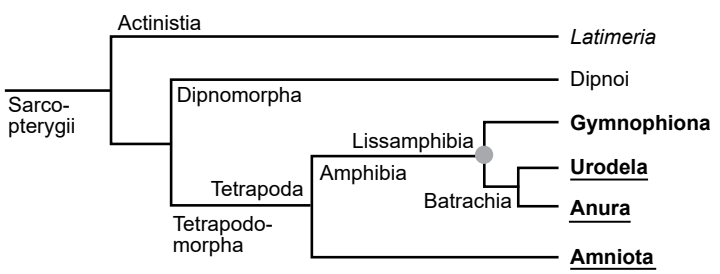

molecular consensus - Lissamphibia

c)

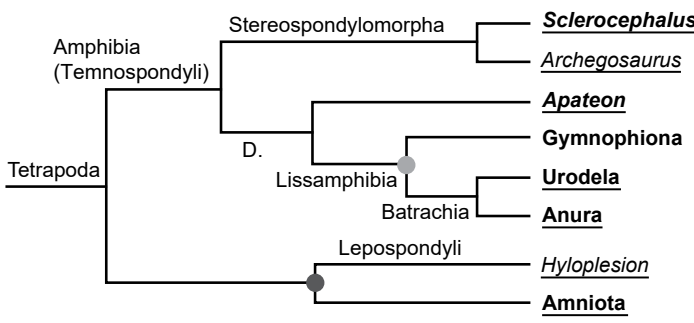

TH

Compatibility:

- Lissamphibia

- Lepospondyli + Amniota

e)

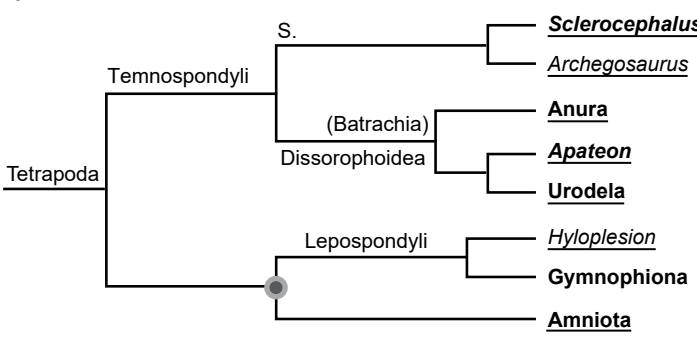

PH1

Compatibility:

not Lissamphibia

- Lepospondyli + Amniota

g)

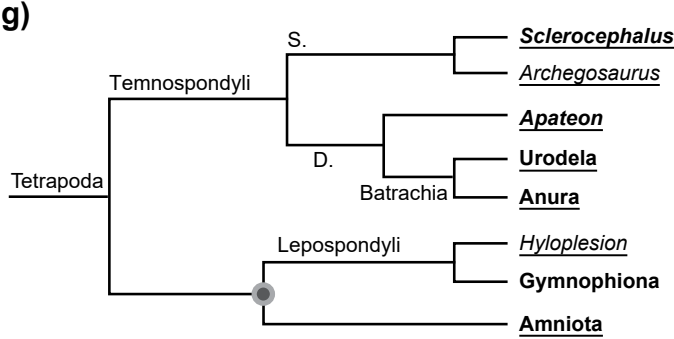

DH1

Compatibility:

not Lissamphibia

- Lepospondyli + Amniota b)

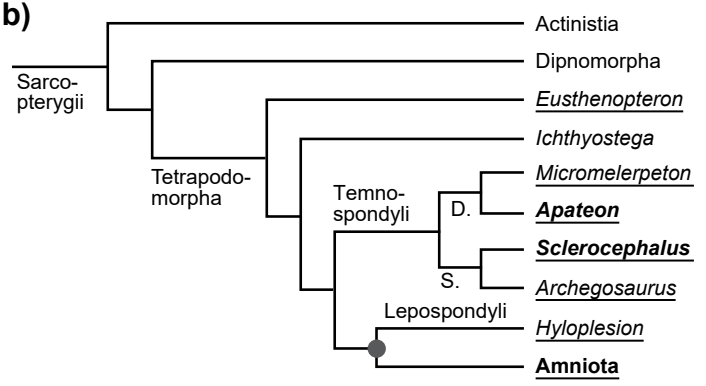

paleontological consensus

- Lepospondyli + Amniota

d)

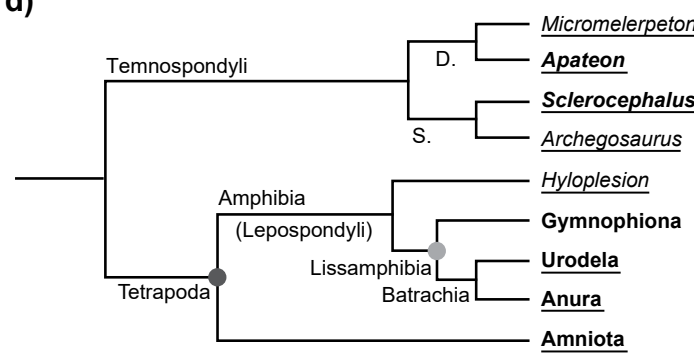

LH

Compatibility:

- Lissamphibia

- Lepospondyli + Amniota

f)

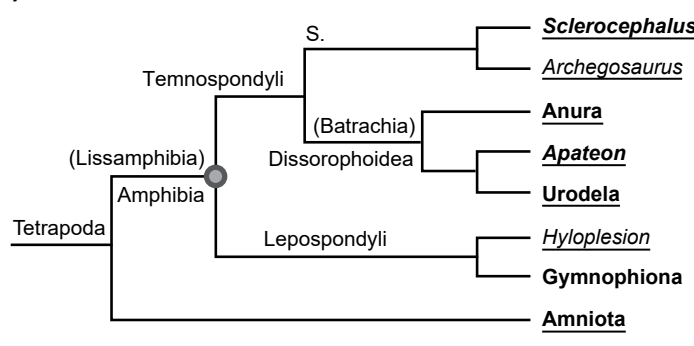

PH2

Compatibility:

Lissamphibia

O not Lepospondyli + Amniota

h)

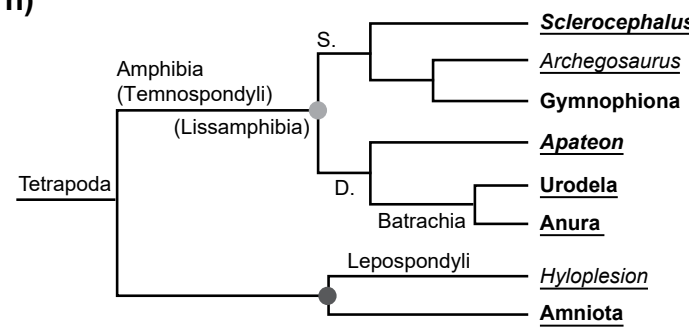

DH2

Compatibility:

Lissamphibia

Lepospondyli + Amniota

Figure 1. (Caption next page) 
Figure 1. (Previous page) Hypotheses on the relationships of the extant amphibian clades since the late 20th century. The names of terminal taxa sampled here for cranial characters are in boldface, those sampled for appendicular characters are underlined; the names of larger clades are placed toward the right end of a branch if they have minimum-clade (node-based) definitions, to the left if they have maximum-clade (branch-based) definitions. Names in parentheses would, given that phylogenetic hypothesis, not be used, but replaced by synonyms. Among terminal taxa, "Melanerpeton" humbergense, sampled for appendicular characters, is not shown, but is always the sister-group of Apateon; Microbrachis, likewise sampled for appendicular characters, is not shown either, but is always the sister-group of Hyloplesion; Eusthenopteron is not shown in c)-h), where it forms the outgroup (b)). See text for Micromelerpeton and for references. The first two trees $(\mathrm{a}, \mathrm{b})$ show the current consensus; the other trees $(\mathrm{c}-\mathrm{h})$ show the various tested paleontological hypotheses. Abbreviations: D., Dissorophoidea; S., Stereospondylomorpha. a) Consensus of the latest phylogenetic analyses of molecular data ; all named clades are therefore extant. Note the monophyly of the extant amphibians (Lissamphibia, marked with a light gray dot) with respect to Amniota. b) Consensus of all recent analyses of Paleozoic limbed vertebrates, omitting the extant amphibian clades. Note the monophyly of "lepospondyls" + amniotes (marked with a dark gray dot). c) TH: "temnospondyl hypothesis". Lissamphibia nested among dissorophoid temnospondyls. Compatible with both a) and b) (gray dots). d) LH: “lepospondyl hypothesis". Lissamphibia nested among "lepospondyls"; consequently, temnospondyls are not crown-group tetrapods. Compatible with both a) and b) (gray dots). e) PH1: "polyphyly hypothesis", first variant. Urodela as dissorophoid temnospondyls close to Apateon, Anura as a separate clade of dissorophoid temnospondyls, Gymnophiona as "lepospondyls". Compatible with b) (dark gray dot) but not with a) (light gray circle). f) PH2: "polyphyly hypothesis", second variant. Like PH1, but with restored monophyly of extant amphibians with respect to amniotes (light gray dot; see a)) at the expense of compatibility with the paleontological consensus concerning the position of temnospondyls, lepospondyls, and amniotes (dark gray circle; see b)). g) DH1: "diphyly hypothesis", first variant. Batrachia as dissorophoid temnospondyls, Gymnophiona as "lepospondyls". Compatible with b) (dark gray dot) but not with a) (light gray circle). h) DH2: "diphyly hypothesis", second variant. Batrachia as dissorophoid temnospondyls, Gymnophiona as stereospondylomorph temnospondyls. Compatible with both $a$ ) and b).

Laurin, 2019 for this fact and a discussion of Bayesian analysis of paleontological datasets). Further, a monophyletic origin of all extant amphibians among lepospondyls has also been proposed (Laurin, 1998; Pawley, 2006, appendix 16; Marjanović and Laurin, 2009, 2013, 2019). This will be referred to below as the lepospondyl hypothesis (LH; Fig. 1d).

Phylogenetic analyses of molecular data cannot distinguish the $\mathrm{TH}$, the $\mathrm{PH} 2$, the $\mathrm{DH} 2$ or the $\mathrm{LH}$ from each other by topology (Fig. 1) because all of these imply lissamphibian monophyly with respect to amniotes, and molecular data are not available from any other tetrapodomorphs. Several other types of data and methods have, however, been used to try to discriminate between the various hypotheses on the origin of extant amphibians. In addition to classical phylogenetic analyses of morphological data matrices, these include the use of molecular dating (Zhang et al., 2005; Marjanović and Laurin, 2007; Pardo et al., 2017a) and stratigraphic data (Marjanović and Laurin, 2008) to compare the inferred divergence dates between the three main extant amphibian clades on the basis of molecular data with predictions based on the fossil record under the $\mathrm{TH}$ and the $\mathrm{LH}$ on one side and the $\mathrm{PH}$ and the $\mathrm{DH}$ on the other. However developmental data, in the form of ossification sequences, have been the second-most frequently used (after classic morphological data) to argue for particular phylogenetic hypotheses. These data include mainly cranial (e.g., Schoch, 2002, 2006; Schoch and Carroll, 2003; Schoch and Milner, 2004; Anderson, 2007; Carroll, 2007; Germain and Laurin, 2009) and autopodial ossification sequences (e.g., Fröbisch et al., 2007, 2015). Ossification sequences of other parts of the skeleton, like the vertebrae, shoulder girdle and scales, are also documented in a few Paleozoic stegocephalians (e.g., Carroll et al., 1999; Witzmann, 2006; Anderson, 2007; Carroll, 2007; Olori, 2013), not to mention finned tetrapodomorphs (Cloutier, 2010), but these have played a minor role in the controversy about the origin of extant amphibians. Recently, Danto et al. (2019) concluded that vertebral ossification sequences varied too quickly and could not be used to assess the origin of lissamphibians. This study relies on both cranial and appendicular ossification sequences and compares their implications for tetrapod phylogeny. 


\section{Material and methods}

\section{Ossification sequence data}

From all the literature we could access, we compiled the most extensive database on ossification sequences for osteichthyans that exists to date. The most useful sources for extant taxa included compilations: Harrington et al. (2013) for amphibians, Weisbecker and Mitgutsch (2010) for anurans, Hugi et al. (2012) for squamates, Maxwell et al. (2010) for birds, and Koyabu et al. (2014) and Weisbecker (2011) for mammals. The cranial and appendicular sequences of Permian temnospondyls (the stereospondylomorphs Sclerocephalus and Archegosaurus, the non-branchiosaurid "branchiosaur" Micromelerpeton and the branchiosaurids "Melanerpeton" humbergense, Apateon caducus and A. pedestris) were assembled from several references cited in the Appendix; note that the two Apateon species are each represented by two different sequences scored after populations from two separate paleo-lakes (Erdesbach and Obermoschel) in which both species occur. Appendicular ossification sequences of the lepospondyls Microbrachis and Hyloplesion are incorporated from Olori (2013), that for the finned tetrapodomorph Eusthenopteron was combined from Cote et al. (2002) and Leblanc and Cloutier (2005).

All sources of our sequence data can be found in the Appendix. The sequences themselves and the phylogenetic trees corresponding to the tested hypotheses are included in the Supplementary information. The sequences were not used to generate the tree topology or the branch lengths (which represent evolutionary time); the tree is compiled from published sources (provided below) which did not use any ossification sequences in their phylogenetic analyses.

The software we used to compute AICc weights, the CoMET module (Lee et al., 2006) for Mesquite 3.6 (Maddison and Maddison, 2018), cannot handle missing data. This unfortunately meant we had to discard much information. In order to keep as many taxa as possible in the analysis, we first compiled a matrix (not shown) of 244 taxa and 213 characters. All of these characters are positions of skeletal elements (cranial, appendicular, axial and others) in ossification sequences, standardized between 0 and 1 following Germain and Laurin (2009), as explained below. Of these, we kept characters that were scored in the Paleozoic taxa in our initial database, and extant taxa that were scored for the same sets of characters. This resulted in two initial datasets, one of cranial and one of appendicular sequences (it was not possible to include both sets of sequences together because this would have left too few taxa in the matrix).

In the end, however, we were left with three overlapping cranial datasets. The largest cranial dataset we could make, dataset 2 of Table 1, has 105 taxa (103 extant, plus the two species of Apateon scored from Erdesbach) and seven characters: the appearance times of the premaxilla, maxilla, nasal, parietal, pterygoid, exoccipital and squamosal bones. It lacks Sclerocephalus, which cannot be scored for the appearance time of the squamosal. This is unfortunate because Sclerocephalus is one of only three extinct taxa for which a usable cranial ossification sequence is known at all, and further because it occupies a special place in the $\mathrm{DH} 2$, according to which it lies on the caecilian stem. We attempted to compensate for this deficiency by assembling two more cranial datasets: dataset 1, which contains 107 taxa (104 extant, Apateon spp. from Erdesbach, and Sclerocephalus) but only six characters by lacking the squamosal, and dataset 5, which includes 84 taxa (81 extant, Apateon spp. from Erdesbach, and Sclerocephalus) and eight cranial characters (the vomer and the frontal bone are added to the six of dataset 1). 
Table 1. List of datasets used in this paper. All are subsets of our global compilation that were selected to meet the requirement of the method used (missing data cannot be handled). The temnospondyl species Apateon caducus and A. pedestris are included in all datasets, but scored after populations from two different paleo-lakes in which both species occur.

\begin{tabular}{|c|c|c|c|c|c|}
\hline Dataset number & 1 & 2 & 3 & 4 & 5 \\
\hline Type of characters & cranial & cranial & appendicular & appendicular & cranial \\
\hline Number of characters & 6 & 7 & 7 & 4 & 8 \\
\hline Number of taxa & 107 & 105 & 62 & 65 & 84 \\
\hline Sclerocephalus & yes & no & yes & yes & yes \\
\hline Source of data for Apateon & Erdesbach & Erdesbach & Obermoschel & Erdesbach and Obermoschel & Erdesbach \\
\hline Additional Paleozoic taxa & None & None & $\begin{array}{l}\text { Archegosaurus, Micromelerpeton, Hyloplesion, } \\
\text { Microbrachis, Eusthenopteron }\end{array}$ & $\begin{array}{l}\text { Archegosaurus, Micromelerpeton, "Melanerpeton" } \\
\text { humbergense, Hyloplesion, Microbrachis, } \\
\text { Eusthenopteron }\end{array}$ & None \\
\hline Tables in which it is used & 2,5 & 3,6 & 4,8 & 4,9 & 7 \\
\hline
\end{tabular}

For the appendicular characters, in addition to dataset 3 which contains seven characters (humerus, radius, ulna, ilium, femur, tibia and fibula) and 62 taxa (54 extant, Apateon spp. from Obermoschel, Sclerocephalus, Archegosaurus, Micromelerpeton, Hyloplesion, Microbrachis and Eusthenopteron), another (dataset 4) includes only four characters (radius, ulna, ilium, and femur), but it features 65 sequences, the additional data being Apateon spp. from Erdesbach and "Melanerpeton" humbergense. See Table 1 for a list of these datasets and the Supplementary information for the datasets themselves.

The data loss in these various datasets is not as severe as it may first seem, because most of the characters that have been excluded from these analyses had less than $10 \%$ scored cells (sometimes less than $1 \%$ ), and most of them could not be scored for any temnospondyl or lepospondyl, so they could not have helped resolve the main question examined in this study.

The order in which the sampled cranial bones ossify varies substantially in our sample of taxa, but based on simple (not phylogenetically-weighted) average position, the frontal appears first, followed closely by the premaxilla, parietal, and maxilla (in close succession), and then by the squamosal, exoccipital, pterygoid, and last by the nasal. However, each of these bones ossifies first (among these bones; not necessarily in the whole skeleton) in at least one of the included taxa. Among the appendicular bones, there is more variability; each ossifies first in at least one of the 62 sampled taxa, and three (radius, ulna and ilium) ossify last in at least one taxon.

Due to the homology problems between the skull bones of tetrapods and actinopterygians and missing data, we had to omit all actinopterygians from our analyses. As cranial ossification sequences remain poorly documented for extant finned sarcopterygians, except perhaps lungfish, whose skull bones seem mostly impossible to homologize (Criswell, 2015), our analyses of those data are restricted to limbed vertebrates. However, for appendicular data, we were able to include the Devonian tristichopterid Eusthenopteron foordi.

Unfortunately, the only cranial ossification sequence available for any supposed lepospondyl, that of the aïstopod Phlegethontia longissima, is documented from only three ossification stages (Anderson et al., 2003; Anderson, 2007). This poses a problem for our analysis method, which assumes that character evolution can be modeled as Brownian motion; this assumption is decreasingly realistic as the number of character states (sequence positions) decreases, because the resulting distribution deviates increasingly from that of a continuous character. Furthermore, some recent anatomical restudies and phylogenetic 
analyses suggest that aïstopods are not lepospondyls, but early-branching stem-stegocephalians (Pardo et al., 2017b; Pardo et al., 2018; Clack et al., 2019; Mann et al., 2019).

The low taxon sample is more limiting for this analysis than the low character sample. However, as explained below, the absence of lepospondyl sequences in our cranial dataset does not preclude testing the six hypotheses $(\mathrm{TH}, \mathrm{PH} 1, \mathrm{PH} 2, \mathrm{DH} 1, \mathrm{DH} 2, \mathrm{LH}$; see above or Figure 1 for the explanation of these abbreviations) because each of these six hypotheses makes different predictions about where temnospondyls and caecilians fit relative to other taxa. Thus, in the absence of lepospondyls in our dataset, the tests of these hypotheses are somewhat indirect and inference-based, but they remain possible. Our tests based on appendicular data include two lepospondyls (Hyloplesion longicostatum and Microbrachis pelikani), but the absence of caecilians in that dataset proves more limiting than the absence of lepospondyls in the cranial dataset because the TH, DH1 and DH2 become indistinguishable (Fig. 1c, $g$, h). However, the presence of the temnospondyl Micromelerpeton allows us to test two variants of the TH/DH distinguished by the monophyly (e.g., Ruta and Coates, 2007) or polyphyly (e.g., Schoch, 2019) of "branchiosaurs" (the temnospondyls Apateon, "Melanerpeton" humbergense and Micromelerpeton).

\section{Sensitivity analysis for sequence polymorphism}

Given the potential impact of intraspecific variability in ossification sequence on inferred nodal sequences and heterochrony (Olori, 2013; Sheil et al., 2014), we compiled two consensus sequences for Apateon caducus and $A$. pedestris each, representing two localities where both species occur, the paleo-lakes of Erdesbach (Schoch, 2004) and Obermoschel (Werneburg, 2018). Based on dataset 4 (see Table 1), we incorporated these into a global and two separate analyses (one analysis per locality) to determine the impact of the observed variability. As detailed above, incorporating the sequences from Erdesbach reduced the number of characters from seven to only four because the software used cannot handle missing data (see above and below), but this information loss is compensated by the great increase in number of sequences from extinct taxa (eleven instead of two, when counting the sequences of Apateon from both localities separately) and the fact that this includes some lepospondyls (see above and below). It would have been even better to perform a sensitivity analysis incorporating variability for all taxa for which such information was available, but given the scope and nature of our study, this would have been exceedingly time-consuming and is best left for the future.

\section{Standardization of the data}

Given that various taxa differ in their numbers of bones and that the resolution of the sequences is also variable between taxa, these data needed to be standardized to make comparisons and computations meaningful, as suggested by Germain and Laurin (2009). Note that we performed this standardization on the complete dataset of characters, before filtering for data completeness. This complete dataset (not shown) includes 213 cranial, appendicular and other characters, but no taxon is scored for all characters, because that matrix has much missing data. For instance, the most completely scored taxon, Amia calva, still has $57.4 \%$ missing data (more than half), which indicates that 92 characters were scored for this taxon, including several ties (the resolution was 41 positions, so they varied by increments of 0.025 or $2.5 \%$ of the recorded ontogeny). We did not re-standardize after filtering characters out because we believe that the initial standardization better reflects the relative position of events in development than a standardization based on only seven events in ontogeny. Because of this, some characters in the reduced datasets lack states 0 or 1 for some taxa. This is simply because the first or last events in the ontogenetic sequence 
were filtered out. Thus, we used the position in the sequence (from first to last, in the complete dataset) and standardized this relative sequence position between 0 and 1 using the formula given by Germain and Laurin (2009). The standardized sequence position $\left(X_{s}\right)$ is:

$$
X_{s}=\left(X_{i}-X_{\min }\right) /\left(X_{\max }-X_{\min }\right)
$$

where:

$X_{i}$ is the position of a given bone in the sequence

$X_{\min }$ is the lowest position in the sequence (generally 0 or 1 )

$X_{\max }$ is the highest position in the sequence (for instance, if there are 20 bones, $X_{\min }$ is 1 and the sequence is completely resolved, $X_{\max }=20$ ).

This yields a standardized scale that varies between 0 and 1 for each taxon, in which 0 and 1 are the positions of the first and last events in the sequence, respectively. For instance, for Ambystoma maculatum (an extant urodele), in the original dataset, the first events (tied) were the ossification of premaxilla, vomer, dentary and coronoid (standardized position: 0); the last event was the articular (standardized position: 1 ), and there is a resolution of 12 positions (hence, increments of 0.0909 or 1/11). However, in the final dataset of 7 characters, the articular is absent; hence, the first bone in the sequence is the premaxilla, at a standardized position of 0 , and the last is the nasal, as a standardized position of 0.8181 because all events in position 1 (articular) and 0.9091 (stapes) have been filtered out.

We also experimented with using size (skull length) or developmental stage as standards, but this led to lower sequence resolution because body size is not available for all sequence positions and for all taxa (results not shown), so we worked only with sequences standardized by position. Given that our data filtering procedure retains few data (only six, seven or eight characters for the cranial dataset, and four or seven characters for the postcranial dataset), it is important to use the method that discards the least amount of data, and this was achieved by using sequence position. We do not imply that standardizing by size is not recommended in general. On the contrary, if good body size data were available for all taxa and all developmental stages, this should be a better strategy, and only having access to absolute time should be even better. However, practical limitations of data availability prevent us from using these methods now.

Our ossification sequence data (reduced dataset of four to eight characters) of extant and extinct taxa, and the phylogenetic trees we used, are available in the Supplementary information.

\section{Analysis methods}

To discriminate between the six hypotheses about the origin of extant amphibians, two methods are available: direct phylogenetic analysis of the sequence data, and comparisons of the tree length (number of steps in regular parsimony, squared length in squared-change parsimony, likelihood, or similar measures) of various trees selected a priori to represent these hypotheses (in these trees, only the position of caecilians and extinct taxa, here temnospondyls and lepospondyls, varies). We used both approaches but expected the second to perform much better because relatively few data are available, and thus, phylogenetic analysis of such data is unlikely to provide a well-resolved tree.

For the first approach, we first transformed the standardized sequence positions back into discrete characters using formulae in a spreadsheet and scaled the characters so that the highest state in all 
would be 9 . This ensures that each character has equal weight in the analysis, regardless of its variability in the ossification sequence. The characters were ordered to reflect the assumed evolutionary model (ontogenetic timing is a quantitative character that was discretized) and because for such characters, ordering yields better results (Rineau et al., 2015, 2018; see discussion in Marjanović and Laurin, 2019). The resulting data matrices (one for cranial and another for appendicular characters, both with seven characters each) were analysed using parsimony in PAUP* 4.0a165 (Swofford, 2019). We used the TBR (tree bisection-reconnection) branch swapping algorithm and performed a search with 50 random addition replicates (or several such searches, for the cranial data) while holding two trees at each step and with a maximum number of trees set at one million. For cranial data, the main search lasted about 100 hours on a MacBook Pro Retina with a $2.5 \mathrm{GHz}$ iCore 7 quadri-core processor and $16 \mathrm{~GB}$ RAM. The exact search time cannot be reported because PAUP* crashed after saving the trees to a file for one of the longest runs (several analyses were made, over several days), but before the log could be saved. The analysis of the seven appendicular characters was much faster (27 minutes and a half), presumably because that matrix has fewer taxa (62 instead of 105).

For the second approach (comparison of fit of various trees selected a priori to reflect previously published hypotheses), we used the CoMET module (Lee et al., 2006) for Mesquite 3.6 (Maddison and Maddison, 2018) to test the relative fit of the data on trees representing the six hypotheses. CoMET calculates the likelihood and the AIC (Akaike Information Criterion) of nine evolutionary models given continuous data and a tree. Note that our data only represent an approximation of continuous data; if standardization had been performed on developmental time or body size, the data would actually have been continuous. Standardization was carried out using sequence position because of data limitation problems, so the data actually follow a decimalized meristic scale. However, the difference between these situations decreases as the number of sequence positions increases, and our global scale includes up to 41 positions (and an average of 10.9 positions), so our data should approximate a continuous distribution sufficiently well for our analyses to be valid. This consideration prevents us from adding the highly apomorphic aïstopod Phlegethontia, for which only three cranial ossification stages are known (Anderson et al., 2003; Anderson, 2007); moreover, five of the eight bones included in our analyses appear in the last two of these stages, one of the relevant bones (vomer) is absent and two (parietal and exoccipital) are not present as separate ossifications, which would create additional missing data. In that case, the very low number of stages would create strong departures from the assumption of continuous data. This would probably create statistical artifacts, and the uncertainty about the position of Phlegethontia (Pardo et al., 2017b; Pardo et al., 2018; Clack et al., 2019; Marjanović and Laurin, 2019) would complicate interpretation of the results.

The nine models evaluated by CoMET are obtained by modifying the branch lengths of the reference tree. Thus, branches can be set to 0 (for internal branches only, to yield a non-phylogenetic model), to 1 (equal or speciational model), left unchanged from their original length (gradual evolution in our case, where the original lengths represent geologic time), or set free and evaluated from the data (free model). This can be applied to internal and/or external branches, and various combinations of these yield nine models (Lee et al., 2006, fig. 1). Among these nine models two have been frequently discussed in the literature and are especially relevant. The first is gradual evolution, in which branch lengths (here representing evolutionary time) have not been changed. The second is the speciational model, in which all branches are set to the same length because changes are thought to occur at speciation events, which are typically equated with cladogeneses in evolutionary models (Bokma et al., 2016). This model has some similarities with Eldredge and Gould's (1972) punctuated equilibria (though a model with one internal branch stemming from each node set to 0 and the other set to 1 would be even closer to the original 
formulation of that model). In this study, we assessed the fit of six of the nine models covered by CoMET; the other three (the punctuated versions of distance [original branch length], equal and free), in which one of each pair of daughter-lineages has a branch length of zero, could not be assessed due to problems in the current version of COMET and possibly the size of our dataset.

Provided that the same evolutionary model is optimal for all compared phylogenetic hypotheses (this condition is met, as shown below), the AIC weights of the various trees under that model can be used to assess the support for each tree. In such comparisons, the topology is part of the evolutionary model, and the data are the sequences. These comparisons can show not only which tree is best supported, but how many times more probable the best tree is compared to the alternatives. This quantification is another reason to prefer this approach over a phylogenetic analysis (performed below, but with the poor results that we anticipated), which can at best yield a set of trees showing where the extinct taxa most parsimoniously fit (if we had dozens of characters, this might be feasible). Comparisons with other hypotheses through direct phylogenetic analysis are not possible. Given the small sample size (which here is the number of characters), we computed the corrected AIC (AICC) and the AICc weights using the formulae given by Anderson and Burnham (2002) and Wagenmakers and Farrell (2004).

Our tests make sense only in the presence of a phylogenetic signal in the data. In addition to the test of evolutionary model in CoMET mentioned above (which tests non-phylogenetic as well as phylogenetic models), we performed a test based on squared-change parsimony (Maddison, 1991) and random taxon reshuffling (Laurin, 2014). For this test, we compared the length of the LH (lepospondyl hypothesis; Fig. 1d) reference tree (with and without Sclerocephalus) to a population of 10,000 random trees produced by taxon reshuffling.

It could be argued that using other methods (in addition to the method outlined above) would have facilitated comparisons with previous studies. However, the two main alternative methods, event-pair cracking with Parsimov (Jeffery et al., 2005) and Parsimov-based genetic inference (PGI; Harrison and Larsson, 2008), have drawbacks that led us to not using them. Our objections against event-pair cracking with Parsimov were detailed by Germain and Laurin (2009). In short, that method requires an unnecessary decomposition of sequences into event pairs, and it cannot incorporate absolute timing information (in the form of time, developmental stage or body size, for instance) or branch length information. More importantly, the simulations performed by Germain and Laurin (2009) showed that event-pair cracking with Parsimov yields more artefactual change and has lower power to detect real sequence shifts. That method is also problematic when trying to infer ancestral sequences and can lead to impossible ancestral reconstructions (e.g. A occurs before B, B occurs before $C$, and C occurs before A), as had been documented previously (Schulmeister and Wheeler, 2004, p. 55). This would create problems when trying to compare the fit of the data on various phylogenetic hypotheses. The performance of Parsimov-based genetic inference (PGl; Harrison and Larsson, 2008) has not been assessed by simulations, but it rests on an edit cost function that is contrary to our working hypothesis (that the timing of developmental events can be modeled with a bounded Brownian motion model, which is assumed by continuous analysis). More specifically, Harrison and Larsson (2008, p. 380) stated that their function attempts to minimize the number of sequence changes, regardless of the magnitude of these changes. We believe that disregarding the size of changes is unrealistic, as shown by the fact that Poe's (2006) analyses of thirteen empirical datasets rejected that model (which he called UC, for unconstrained change) in favor of the model we accept (AJ for adjacent states, which favors small changes over large ones). Furthermore, analyses of ossification sequence data using techniques for continuous data as done here (see above) have been performed by an increasingly large number of studies (e.g., Skawiński and Borczyk, 2017; Spiekman and 
bioRxiv preprint first posted online Jun. 20, 2018; doi: http://dx.doi.org/10.1101/352609. The copyright holder for this preprint (which was not peer-reviewed) is the author/funder, who has granted bioRxiv a license to display the preprint in perpetuity.

All rights reserved. No reuse allowed without permission.
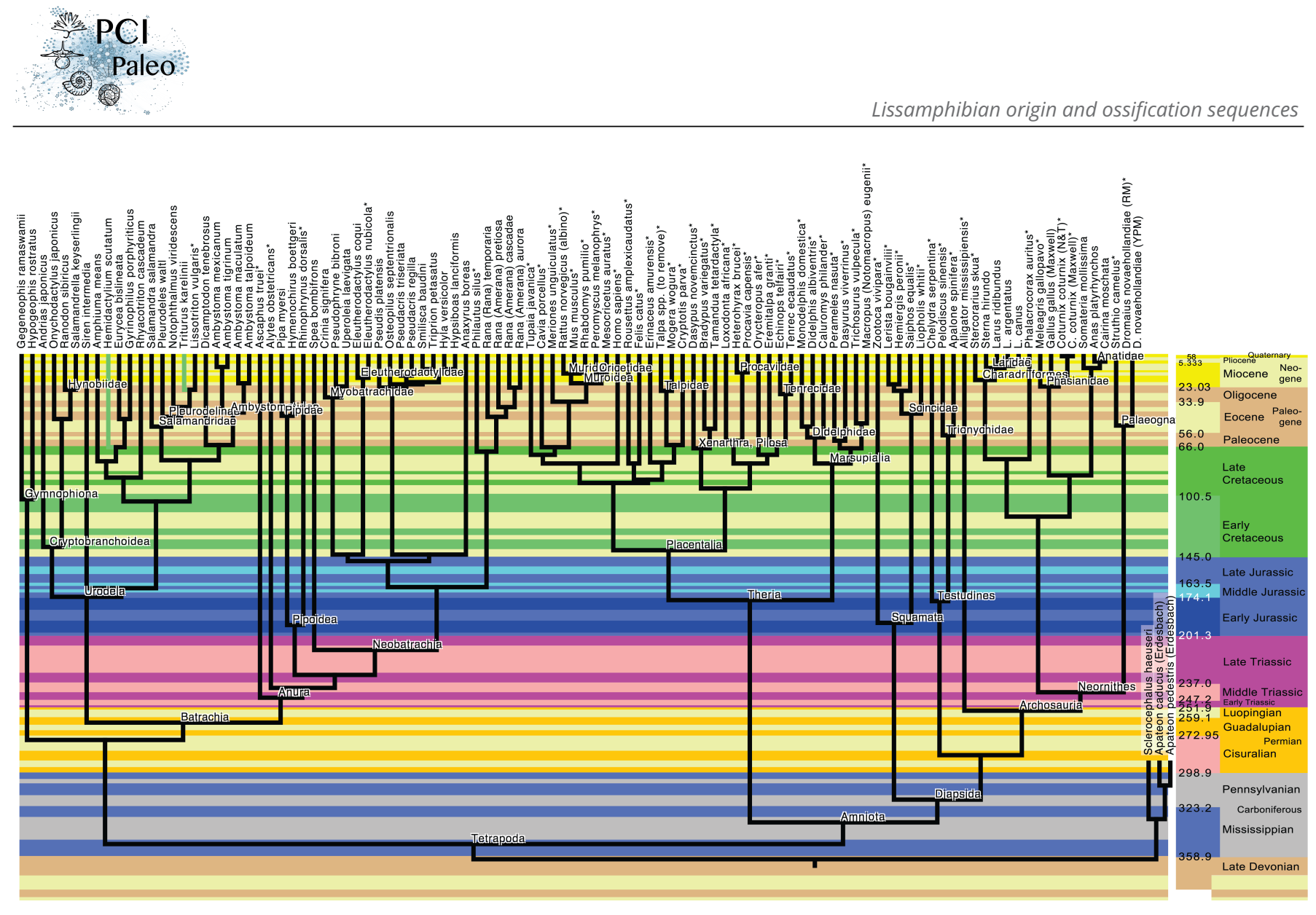

Figure 2. Reference phylogeny used for some of the analyses, illustrating the LH (lepospondyl hypothesis) of lissamphibian origins. The tree was time-calibrated, but analyses showed that branch lengths are irrelevant, given that the best model is speciational (Tables 2-4). Main sources for topology and divergence times: Reeder (2003); Brandley et al. (2005); Pons et al. (2005); Lecompte et al. (2008); Bossuyt and Roelants (2009); Germain and Laurin (2009); Hugall et al. (2007); Gonzalez et al. (2009); Meredith et al. (2011); Sterli et al. (2013); Wang et al. (2013); Marjanović and Laurin (2014, 2019)); Pyron (2014); Rabosky et al. (2014); Schoch (2014b); Prum et al. (2015); Zhuang et al. (2015); Tarver et al. (2016); Feng et al. (2017); Irisarri et al. (2017); Lu et al. (2017); Pardo et al. (2017a); Jetz and Pyron (2018). The colored bands represent geological stages from the international geological timescale (Ogg et al., 2016).

Werneburg, 2017; Werneburg and Geiger, 2017; just to mention papers published in 2017), so the issue of ease of comparisons of our results with other studies is not as serious as it would have been only a few years ago, and it should be decreasingly so in the future.

\section{Reference phylogenies}

We built a reference timetree that attempts to capture the established consensus (Fig. 2; see the next paragraphs for the sources). The tree was compiled in Mesquite versions up to 3.6 (Maddison and Maddison, 2018) and time-calibrated using the Stratigraphic Tools module for Mesquite (Josse et al., 2006). For consistency and to avoid the effects of gaps in the fossil record, we used molecular divergence dates whenever possible. The tree had to be time-scaled because many of the evolutionary models that we fit on the tree in the first series of tests (to determine which evolutionary model can be used to compare the fit of the hypotheses) use branch lengths to assess model fit. Note that our procedure requires estimating divergence times between all taxa (geological ages of all nodes). When taxa are pruned, branch lengths are adjusted automatically. The main sources we used for topology and divergence times (and hence branch lengths) are as follows. 
The phylogeny of lissamphibians follows the work of Jetz and Pyron (2018). However, several other sources have been used for the temporal calibration of the tree: Germain and Laurin (2009) was used for the urodeles, whereas Feng et al. (2017), supplemented by Bossuyt and Roelants (2009) and Pyron (2014), was used for the anurans as well as more rootward nodes (Batrachia, Lissamphibia, Tetrapoda; also Amniota). Marjanović and Laurin (2014) was used for the Ranidae, Ceratophryidae and Hylidae.

The sediments that have preserved the temnospondyls Apateon and Sclerocephalus are not easy to correlate with each other or with the global chronostratigraphic scale. Combining stratigraphic information from Schoch (2014b), Schneider et al. (2015) and Werneburg (2018), we have placed all three sampled species (A. pedestris, A. caducus, S. haeuseri) at the Sakmarian/Artinskian stage boundary (Permian; 290.1 Ma ago); combining stratigraphic information from Schneider et al. (2015) with the phylogeny in Schoch (2014b), we have tentatively placed the divergence between the two Apateon species (which are not sister-groups: Schoch, 2014b) at the Kasimovian/Gzhelian stage boundary (Carboniferous; $303.7 \mathrm{Ma}$ ago). The age of the last common ancestor of Apateon and Sclerocephalus depends strongly on temnospondyl phylogeny, which remains unresolved (Pardo et al., 2017a; Marjanović and Laurin, 2019; and numerous references in both); as a compromise between the various options, we have provisionally placed it at the boundary between the Early and the Late Carboniferous (Serpukhovian/ Bashkirian, 323.2 Ma ago) where applicable.

We sampled many extant amniotes to achieve broad coverage of Tetrapoda. For the birds, Pons et al. (2005) was used for the Laridae, Wang et al. (2013) for the Phasianidae and Gonzalez et al. (2009) for the Anatidae. The temporal calibration was taken from Prum et al. (2015) as recommended by Berv and Field (2018); gaps were filled in using the database www.birdtree.org.

Several papers, mainly Tarver et al. (2016), were used for the phylogeny and divergence times of mammals. For the Muridae, three references were used: Lecompte et al. (2008), Zhuang et al. (2015), and Lu et al. (2017) for the position of two taxa: Mesocricetus auratus and Peromyscus melanophrys. Other species were placed following the work of Meredith et al. (2011), which also gives divergence times. We caution, however, that all available molecular dates for Paleogene and earlier mammal nodes are controversial and may be overestimates (Berv and Field, 2018; Phillips and Fruciano, 2018).

Three references were also used to integrate squamates in the phylogenetic tree and for the calibration of divergence times: Brandley et al. (2005), Rabosky et al. (2014), Reeder (2003). Sterli et al. (2013) was used for turtles.

For turtles, there is now a near-consensus that they are diapsids, a hypothesis that is not necessarily incompatible with an origin among "parareptiles" (Laurin and Piñeiro, 2017). Thus, following most recent phylogenetic analyses of molecular data (e.g., Hugall et al., 2007; Irisarri et al., 2017), we have inserted them as the sister-group of Archosauria.

We disagree with several of the calibration dates in Irisarri et al. (2017), which often appear unreasonably old. For instance, they place the divergence between caecilians and batrachians and the divergence between anurans and urodeles in the Early Carboniferous, around 330 and $320 \mathrm{Ma}$, respectively, but our thorough analyses of the fossil record, with due consideration of its incompleteness, suggest significantly more recent dates, in the Permian (Marjanović and Laurin, 2007, 2008, 2014). This is not surprising because some of the dating constraints used by Irisarri et al. (2017, table S8) are wrong. For instance, they enforced a minimal divergence age between cryptodiran and pleurodiran turtles of $210 \mathrm{Ma}$ (Late 
Triassic), but all analyses of the last fifteen years (e.g., Sterli et al., 2013, 2018) strongly suggest that the oldest known turtles that fit within this dichotomy date from the Late Jurassic, less than $165 \mathrm{Ma}$. The divergence between humans and armadillos (boreotherian and xenarthran placentals) was constrained to the middle of the Cretaceous (95.3-113 Ma), based on outdated literature that assigned a wide variety of stem-eutherians to highly nested positions in the placental crown; there are currently no clear placentals known from any Cretaceous sediments even as young as 66 Ma (e.g., Halliday et al., 2016, 2017; Davies et al., 2017; Phillips and Fruciano, 2018), barely half the age of the older end of the constraint range. Conversely, the divergence between diapsids (hence sauropsids) and synapsids had a minimal age constraint of $288 \mathrm{Ma}$ (Early Permian), which is much too young given the presence of sauropsids (and presumed synapsids) in Joggins, in sediments that have recently been dated (Carpenter et al., 2015) around 317-319 Ma (early Late Carboniferous). Thus, we have not used divergence dates from that source.

To discriminate among the hypotheses on lissamphibian origins, we inserted the temnospondyl Apateon in the tree where each predicts that it should be (Fig. 1c-h). Thus, according to the TH (temnospondyl hypothesis; Fig. 1c), Apateon lies on the lissamphibian stem. Under the LH (lepospondyl hypothesis; Fig. 1d), Apateon lies on the tetrapod stem. Under both versions of the DH (diphyly hypothesis; Fig. 1g, h), Apateon lies on the batrachian stem. Under both versions of the PH (polyphyly hypothesis; Fig. 1e, f), Apateon lies on the caudate stem. Within the $\mathrm{DH}$ and the $\mathrm{PH}$, both versions of each differ in the position of Gymnophiona. Thus, despite the absence of any lepospondyl in our cranial ossification sequence datasets, our taxonomic sample allows us to test all these competing hypotheses. The appendicular datasets allow more direct tests of some of these hypotheses because they include two lepospondyl taxa, which were likewise placed in trees representing the tested hypotheses (Fig. 1).

Sclerocephalus is the sister-group of Apateon under the LH (Fig. 1d), immediately rootward of it (on the lissamphibian stem) under the TH (Fig. 1c) and likewise (but on the batrachian stem) under the DH1 (Fig. 1g), on the caecilian stem under the DH2 (Fig. 1h) and the sister-group of Batrachia (including Apateon) under both versions of the PH (Fig. 1e, f).

"Melanerpeton" humbergense (appendicular data only) is the sister-group of Apateon in all trees, except under the hypothesis of branchiosaur paraphyly; Eusthenopteron (appendicular data only) forms the outgroup in all trees.

The lepospondyls Microbrachis and Hyloplesion, from both of which only appendicular data are available, form an exclusive clade (Clack et al., 2019; Marjanović and Laurin, 2019). This clade is the sister-group of Lissamphibia (represented only by Batrachia because caecilians are lacking from the appendicular datasets) under the $\mathrm{LH}$, of Amniota under the $\mathrm{TH}$ and both versions of the $\mathrm{DH}$ (these three cannot be distinguished due to the absence of caecilians) as well as under the PH1, and of Temnospondyli (including Batrachia) under the $\mathrm{PH} 2$ (see the legend of Figure 1 for an explanation of these abbreviations).

The temnospondyl Micromelerpeton, from which likewise only appendicular data are available, forms the sister-group of Apateon under the LH. The uncertainty over its phylogenetic position within Dissorophoidea (as the sister-group to the rest, including anurans and urodeles: e.g. Schoch, 2019; as the sister-group of Apateon + "Melanerpeton" humbergense: e.g. Ruta and Coates, 2007; Marjanović and Laurin, 2019) generates two versions of the TH/DH1/DH2 tree for the appendicular dataset. We tested both of these versions against that dataset, for a total of five trees. 

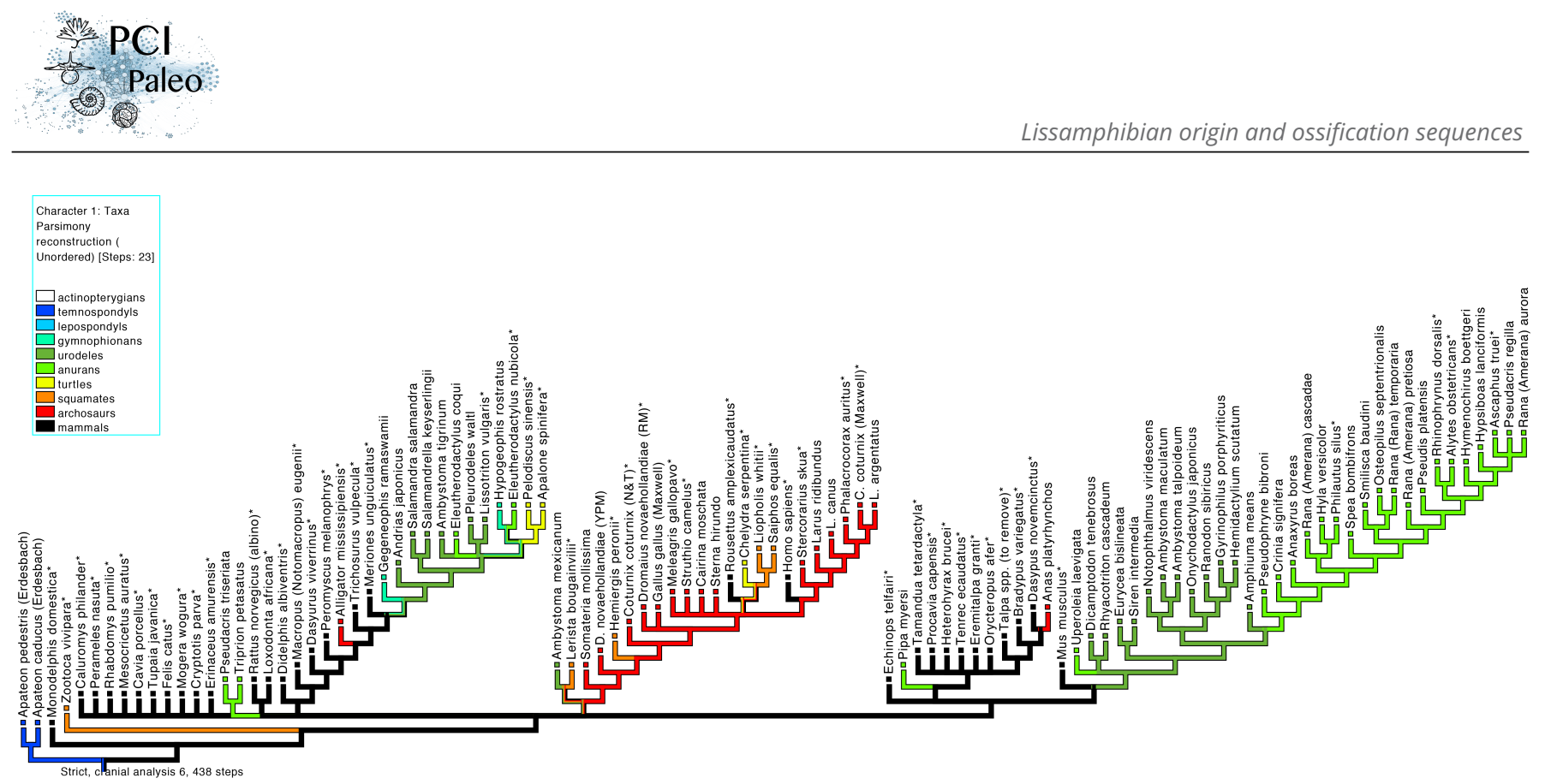

Figure 3. Strict consensus of the most parsimonious trees obtained by analyzing cranial dataset 2. Dataset 2 comprises 105 taxa and seven characters (see Table 1). Note that several higher taxa whose monophyly is well-established are para- or polyphyletic here. Abbreviations: C., Coturnix; L., Larus. Asterisks meaningless.

To ensure that our analyses were not biased in favor of a given hypothesis, and in case that a continuous evolutionary model were favored, we initially adjusted the branch lengths such that the sum of branch lengths was equal between the compared topologies and that the root was approximately at the same age (in this case in the Tournaisian, the first stage of the Carboniferous). This was done for the trees used to compare the hypotheses using the cranial dataset because if a model incorporating (variable) branch length information had been selected, and if the trees representing the various hypotheses had not all had the same total length (the sum of all branch lengths), the resulting distortions in branch lengths created around the extinct taxa (whose height compared to extant taxa is specified by their geological age) would have introduced another variable influencing the AICc. But given that the selected model ignores branch lengths, this precaution turned out to be superfluous. We have therefore not made these time-consuming adjustments to the additional trees we generated later to analyze the appendicular data.

\section{Results}

In the phylogenetic analysis of cranial data, a single tree island of 22,077 trees of 438 steps was found, only once, so there might be more trees of that length and perhaps even shorter trees. Initially, an island of 22,075 trees was found; we swapped on each of these in a subsequent run, which only recovered two additional trees. Given that slightly longer trees did not differ much from those that we obtained, the low quality of the results (poor congruence with the established consensus about the monophyly of major clades such as squamates, birds, mammals and turtles) and the fact that about four full days of computer time had been spent on analysis of the cranial data, we did not pursue that search further. As expected, the strict consensus tree is poorly resolved (Fig. 3). The majority-rule consensus (not shown, but available in the Supplementary information) is more resolved but not necessarily better because much of the additional resolution contradicts the established consensus. For the appendicular matrix, 22,757 trees of 164 steps were found. Their strict consensus (Fig. 4) deviates even more from the established consensus than the tree obtained from cranial data. 


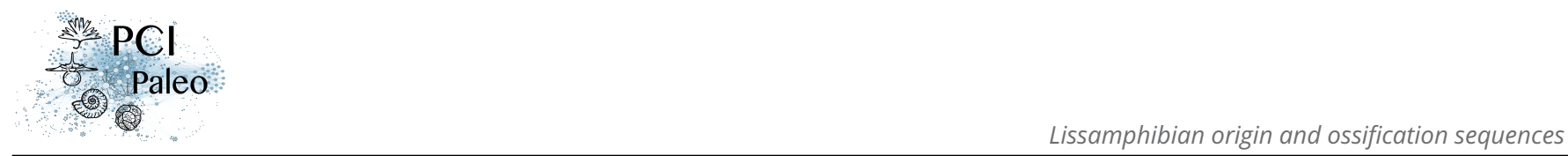

\begin{tabular}{|l|}
\hline Character 1: Taxa \\
Parsimony \\
reconstruction ( \\
Unordered) [Steps: 28] \\
\\
\begin{tabular}{|l} 
actinopterygians \\
temnospondyls \\
\hline lepospondyls \\
\hline gymnophionans \\
\hline urodeles \\
\hline anurans \\
\hline turtles \\
\hline squamates \\
\hline archosaurs \\
mammals
\end{tabular} \\
\hline
\end{tabular}
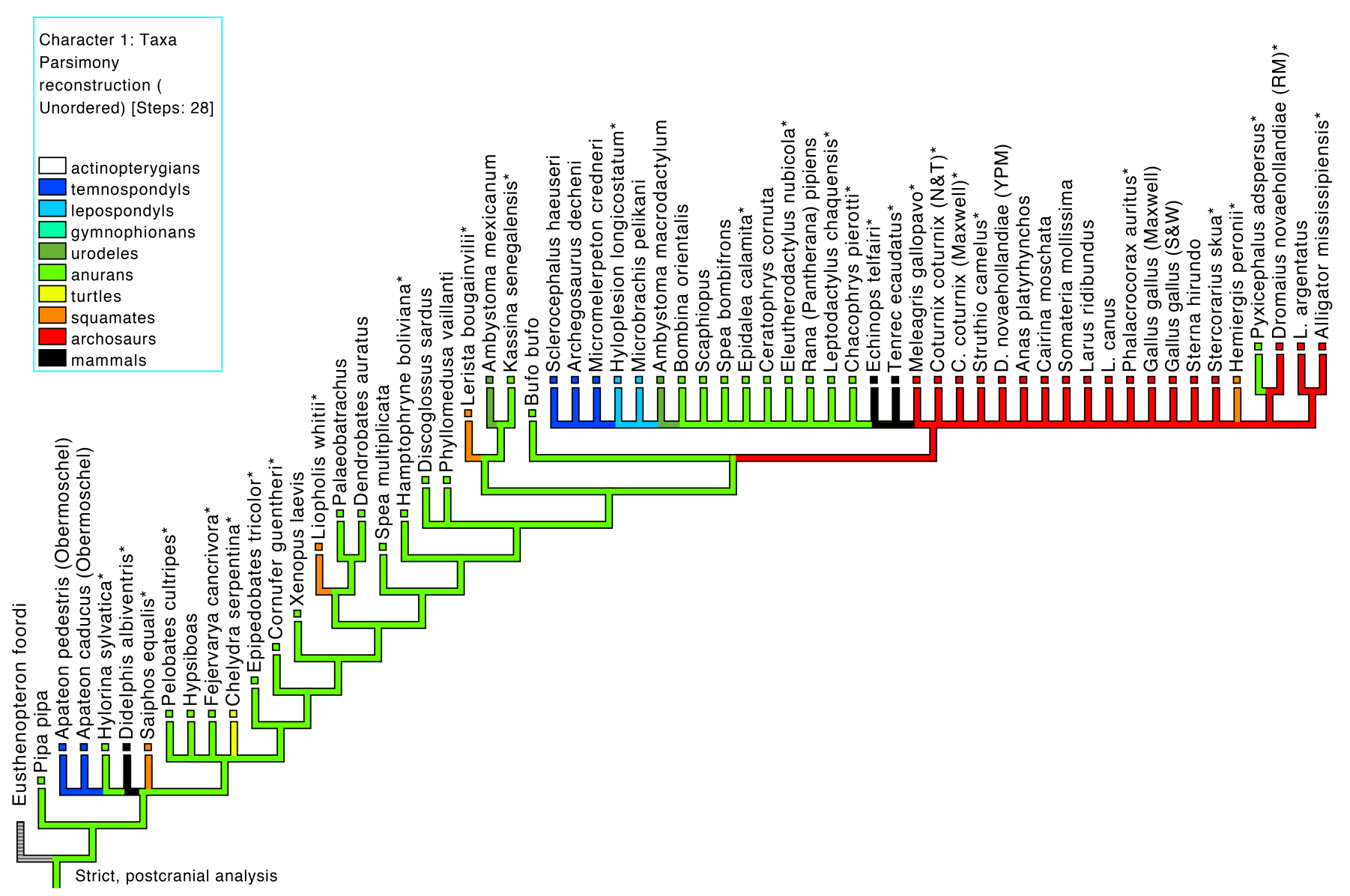

Figure 4. Strict consensus of the most parsimonious trees obtained by analyzing appendicular dataset 3. Dataset 3 comprises 62 taxa and seven characters (see Table 1). The phylogenetic signal in these data seems to be lower than in the cranial data. See Fig. 3 for abbreviations.

This visual assessment of phylogenetic signal through an examination of the consensus trees (Figs. 3, 4 ) is congruent with the test based on squared-change parsimony and random taxon reshuffling (Laurin, 2004). Indeed, the latter indicates that the phylogenetic signal in the cranial data is fairly strong, with a probability of less than 0.0001 that the observed covariation between the data and the tree reflects a random distribution (none of the 10,000 random trees generated were as short as the reference tree). However, it is weaker, with a probability of 0.0017 , for the appendicular data.

The speciational model of evolution, in which all branch lengths are equal, has overwhelming support among cranial data, whether or not the Permian temnospondyl Sclerocephalus (Table 2) or the squamosal (Table 3) are included (including Sclerocephalus adds a second temnospondyl genus, but given that the timing of ossification of the squamosal is unknown in Sclerocephalus, including it requires excluding the squamosal from the analysis as described in the Methods section); the five other examined models have AICc weights $<10^{-11}$. For the appendicular data, the speciational model also has the most support, but that support is not as strong and varies depending on which dataset is analyzed (seven characters or four) and under which phylogenetic hypothesis. In three of the four tests performed, support for the second-best model, the non-phylogenetic/equal model, varied between 5\% and 19\% (Table 4).

Two main conclusions can be drawn from these tests (Tables 2-4). First, given that both of the bestsupported models imply equal branch lengths, actual time represented by branches can be ignored, so we compare support of the six competing topologies using only the best-supported model (speciational). 
Table 2. Support (AICC and AICC weights) for six evolutionary models given our reference tree (LH) and dataset 1 (see Table 1). Dataset 1 comprises six cranial characters (nasal, parietal, squamosal, maxilla, pterygoid, and exoccipital) scored in 107 taxa, including the temnospondyl Sclerocephalus. This was performed on the tree representing the LH (lepospondyl hypothesis), but doing this on other trees leads to similar results. Numbers presented with four significant digits; best values in boldface. "Distance" refers to keeping the original branch length (which represent evolutionary time), "equal" sets all branch lengths (internal and terminal) to 1, "free" infers them from the data. Abbreviations: k, number of estimable parameters; L, likelihood; wi, weight; $\Delta_{i}$, difference of AICc from that of the Pure-Phylogenetic / Equal model.

\begin{tabular}{lllllll}
\hline Evolutionary model & AIC & $\mathbf{L}$ & $\mathbf{k}$ & AICc & $\Delta_{i}$ AICc & wi(AICc) \\
\hline Pure-Phylogenetic / Distance & -584.4 & 293.2 & $\mathbf{1}$ & -583.4 & 641.2 & $5.85 E^{-140}$ \\
Pure-Phylogenetic / Equal (speciational) & $\mathbf{- 1 2 2 5 . 6}$ & $\mathbf{6 1 3 . 8}$ & $\mathbf{1}$ & $\mathbf{- 1 2 2 4 . 6}$ & $\mathbf{0}$ & $\mathbf{1 . 0 0 0}$ \\
Pure-Phylogenetic / Free & $2.000 E^{10}$ & $-1.000 E^{10}$ & 486 & $2.000 E^{10}$ & $2.000 E^{10}$ & $<E^{-165}$ \\
Non-Phylogenetic / Distance & -473.6 & 237.8 & $\mathbf{1}$ & -472.6 & 752.0 & $4.97 E^{-164}$ \\
Non-Phylogenetic / Equal & -959.9 & 481.0 & $\mathbf{1}$ & -958.9 & 265.7 & $2.02 E^{-58}$ \\
Non-Phylogenetic / Free & $2.000 E^{10}$ & $-1.000 E^{10}$ & 244 & $2.000 E^{10}$ & $2.000 E^{10}$ & $<E^{-165}$ \\
\hline
\end{tabular}

Table 3. Support (AICc and AICc weights) for six evolutionary models given our reference tree (LH) and

dataset 2 (see Table 1). Dataset 2 comprises seven cranial characters (nasal, parietal, squamosal, premaxilla, maxilla, pterygoid, and exoccipital) and 105 taxa, excluding Sclerocephalus. Abbreviations and boldface as in Table 2.

\begin{tabular}{lllllll}
\hline Evolutionary model & AIC & $\mathbf{L}$ & $\mathbf{k}$ & AICc & $\Delta_{i}$ AICc & wi(AICc) \\
\hline Pure-Phylogenetic / Distance & -715.9 & 359.0 & $\mathbf{1}$ & -714.9 & 683.5 & $<E^{-26}$ \\
Pure-Phylogenetic / Equal (speciational) & $\mathbf{- 1 3 9 9 . 5}$ & $\mathbf{7 0 0 . 7}$ & $\mathbf{1}$ & $\mathbf{- 1 3 9 8 . 5}$ & $\mathbf{0}$ & $\mathbf{1 . 0 0 0}$ \\
Pure-Phylogenetic / Free & $2.000 E^{10}$ & $-1.000 E^{10}$ & 306 & $2.000 E^{10}$ & $2.000 E^{10}$ & 0 \\
Non-Phylogenetic / Distance & -580.6 & 291.3 & $\mathbf{1}$ & -579.6 & 818.8 & $<E^{-26}$ \\
Non-Phylogenetic / Equal & -1106.0 & 554.0 & $\mathbf{1}$ & -1105.0 & 293.5 & $2.278 E^{-98}$ \\
Non-Phylogenetic / Free & $2.000 E^{10}$ & $-1.000 E^{10}$ & 244 & $2.000 E^{10}$ & $2.000 E^{10}$ & $<E^{-26}$ \\
\hline
\end{tabular}

This simplifies the discussion, because it means that the original branch lengths are irrelevant (under that model, all branch lengths are equal); unfortunately, the branch length (evolutionary time) data were needed to reach this conclusion. Thus, the only remaining variable is the topology. Second, model fitting, along with the test based on squared-change parsimony and random taxon reshuffling, indicates that the phylogenetic signal in the cranial data is strong, but that it is noticeably weaker in the appendicular data (this is shown mostly by the non-negligible support for the non-phylogenetic/equal model). Thus, comparisons of the fit of the various phylogenetic hypotheses for the cranial data should be more reliable than for the appendicular data. However, given that for several Paleozoic taxa (most importantly both of the sampled lepospondyls), comparisons can be performed only for the appendicular data, these were performed as well.

Using the speciational model, the AICc weights of the six compared topologies indicate that there is strong support in the cranial data for the LH (lepospondyl hypothesis), with an AICc weight of 0.9885 when Sclerocephalus is included (Table 5) and 0.8848 when the squamosal is included instead (Table 6). Of the other topologies, the TH (temnospondyl hypothesis) was by far the best supported, with an AICc weight of 0.01144 (with Sclerocephalus) or 0.1056 (with the squamosal), which is 86.44 or 8.38 times less than for the $\mathrm{LH}$. Both versions of the $\mathrm{DH}$ (diphyly hypothesis) and of the $\mathrm{PH}$ (polyphyly hypothesis) have negligible support (AICc weights $<0.01$ when the squamosal is included, $<0.0001$ when Sclerocephalus is included). The least support is found for the $\mathrm{PH} 2$ when Sclerocephalus is included, and for the $\mathrm{DH} 1$ when the squamosal is included. In both cases, the recently proposed DH2 (Pardo et al., 2017a) fares 
Table 4. AICc weights showing relative support for six evolutionary models given our appendicular datasets (3 and 4; see Table 1) and various hypotheses. Because of the number of analyses presented below, only the AICc weights are presented (best values in boldface). Abbreviations: DH, diphyly hypothesis (both versions); $\mathrm{LH}$ lepospondyl hypothesis; $\mathrm{TH}$, temnospondyl hypothesis.

\begin{tabular}{lllll}
\hline Evolutionary model & $\mathbf{7}$ characters, LH & $\mathbf{7}$ characters, LH & $\mathbf{4}$ characters, LH & $\mathbf{4}$ characters, TH/DH \\
\hline Pure-Phylogenetic / Distance & $5.1857 E^{-149}$ & $2.340 E^{-70}$ & $1.227 E^{-52}$ & $2.646 E^{-52}$ \\
Pure-Phylogenetic / Equal & $\mathbf{1}$ & $\mathbf{0 . 9 3 3 5}$ & $\mathbf{0 . 9 4 4 5 9}$ & $\mathbf{0 . 8 1 3 9}$ \\
Pure-Phylogenetic / Free & $<E^{-179}$ & $1.598 E^{-277}$ & $4.012 E^{-158}$ & $3.002 E^{-155}$ \\
Non-Phylogenetic / Distance & $7.515 E^{-179}$ & $4.843 E^{-52}$ & $2.162 E^{-42}$ & $7.262 E^{-42}$ \\
Non-Phylogenetic / Equal & $2.14914 E^{-64}$ & $6.648 E^{-2}$ & $5.541 E^{-2}$ & 0.1861 \\
Non-Phylogenetic / Free & $<E^{-179}$ & $<E^{-179}$ & $<E^{-179}$ & $<E^{-179}$ \\
\hline
\end{tabular}

Table 5. Support (AIC and AICC weights) for the six topologies, reflecting the six hypotheses about the origin of extant amphibians, under the speciational model (called Pure-Phylogenetic / Equal in Tables 2-4), with dataset 1 (see Table 1). Dataset 1 includes six cranial characters (nasal, parietal, squamosal, maxilla, pterygoid, and exoccipital) and 107 taxa (including, among Paleozoic taxa, Apateon and Sclerocephalus). Abbreviations and boldface as in Table 2, except $\Delta_{i}$ : difference of AICc from that of the LH. Hypotheses from top to bottom: TH: monophyletic origin among temnospondyls; LH: monophyletic origin from lepospondyls; DH1: diphyletic origin, caecilians from lepospondyls and batrachians from temnospondyls, as in Anderson et al. (2008); DH2: diphyletic origin, (batrachians and caecilians from different temnospondyls: Pardo et al., 2017a); PH1: triphyletic (polyphyletic) origin with anurans and urodeles from different temnospondyls, caecilians from lepospondyls, and lepospondyls closer to Amniota than to Batrachia (Fröbisch et al., 2007); PH2: triphyletic (polyphyletic) origin as above, but with lepospondyls and caecilians closer to temnospondyls than to amniotes (Milner, 1993), reflecting the well-established lissamphibian monophyly among extant taxa (e.g., Feng et al., 2017; Irisarri et al., 2017).

\begin{tabular}{llllll}
\hline Hypothesis & AIC & $\mathbf{L}$ & AICc & $\Delta_{i}$ AICc & wi(AICc) \\
\hline TH & -1217 & 609.4 & -1215 & 8.919 & 0.01144 \\
LH & $\mathbf{- 1 2 2 6}$ & $\mathbf{6 1 3 . 8}$ & $\mathbf{- 1 2 2 4}$ & $\mathbf{0}$ & $\mathbf{0 . 9 8 8 5}$ \\
DH1 & -1204 & 602.9 & -1202 & 21.90 & $1.738 E^{-5}$ \\
DH2 & -1195 & 598.3 & -1193 & 31.01 & $1.827 E^{-7}$ \\
PH1 & -1194 & 597.9 & -1192 & 31.86 & $1.196 E^{-7}$ \\
PH2 & -1193 & 597.4 & -1191 & 32.89 & $7.143 E^{-8}$ \\
\hline
\end{tabular}

second-worst by a small margin. Notably, the $\mathrm{DH} 1$ contradicts the modern consensus on lissamphibian monophyly (Fig. 1g), while the $\mathrm{PH} 2$ and the $\mathrm{DH} 2$ fulfill this constraint from the molecular but not the paleontological point of view, having lissamphibian monophyly with respect to amniotes but not with respect to temnospondyls (Fig. $1 \mathrm{f}, \mathrm{h}$ ).

A slightly different dataset (only 84 taxa, but eight cranial characters - excluding the squamosal but including the frontal and the vomer - and Apateon sequences for both species from Erdesbach rather than Obermoschel) provides even stronger support for the LH, with an AICc weight of 0.9935 (Table 7). The next best-supported topology, which simultaneously represents the $\mathrm{TH}, \mathrm{DH} 1$ and $\mathrm{DH} 2$ (due to the absence of caecilians from this dataset), has an AICc weight of only 0.0065 .

The appendicular data are available in far more Paleozoic taxa than the cranial data; these include Sclerocephalus haeuseri, Archegosaurus decheni, and the non-branchiosaurid "branchiosaur" Micromelerpeton credneri among temnospondyls, the lepospondyls Hyloplesion longicaudatum and Microbrachis pelikani, and the tristichopterid finned stem-tetrapodomorph Eusthenopteron foordi, in addition to the same two 
Table 6. Support (AIC and AICc weights) for the six topologies, reflecting the six hypotheses about the origin of extant amphibians, for dataset 2 (see Table 1). Dataset 2 includes seven cranial characters (nasal, parietal, squamosal, premaxilla, maxilla, pterygoid, and exoccipital) and 105 taxa, excluding Sclerocephalus (among Paleozoic taxa, only Apateon is present). Abbreviations, boldface and hypotheses as in Tables 2 and 5.

\begin{tabular}{llllll}
\hline Hypothesis & AIC & $\mathbf{L}$ & AICc & $\Delta_{i}$ AICc & wi(AICc) \\
\hline TH & -1395 & 698.6 & -1394 & 4.251 & 0.1056 \\
LH & -1399 & $\mathbf{7 0 0 . 7}$ & $\mathbf{- 1 3 9 8}$ & $\mathbf{0}$ & $\mathbf{0 . 8 8 4 8}$ \\
DH1 & -1384 & 693.1 & -1383 & 15.203 & $4.42 E^{-4}$ \\
DH2 & -1385 & 693.6 & -1384 & 14.315 & $6.89 E^{-4}$ \\
PH1 & -1387 & 694.5 & -1386 & 12.404 & $1.792 E^{-3}$ \\
PH2 & -1390 & 695.8 & -1388 & 9.792 & $6.615 E^{-3}$ \\
\hline
\end{tabular}

Table 7. Support for the various hypotheses about amphibian origins for dataset 5 (see Table 1). Dataset 5 includes eight cranial characters (frontal added) and 84 taxa, with Apateon sequences from Erdesbach (in addition to Sclerocephalus among Paleozoic taxa). Abbreviations, boldface and hypotheses as in Tables 2 and 5. Because of the taxon sample, only three topologies can be tested.

\begin{tabular}{llllll}
\hline Hypothesis & AIC & L & AICc & $\Delta_{i}$ AICc & wi(AICc) \\
\hline LH & $\mathbf{- 1 2 9 6}$ & $\mathbf{6 4 9 . 0}$ & $\mathbf{- 1 2 9 4}$ & $\mathbf{0}$ & $\mathbf{0 . 9 9 3 5}$ \\
TH, DH1, DH2 & -1286 & 644.0 & -1284 & 10.061 & $6.493 E^{-3}$ \\
PH1, PH2 & -1274 & 638.0 & -1272 & 22.038 & $1.628 E^{-5}$ \\
\hline
\end{tabular}

species of Apateon as for the cranial datasets, A. caducus and A. pedestris. Analysis of these data (seven characters: humerus, radius, ulna, ilium, femur, tibia and fibula) yields surprising results, with the $\mathrm{PH} 2$ having the most support, with an AICc weight of 0.7978 when using the dataset of seven bones (Table 8). The TH, DH1 and DH2 with "branchiosaur" monophyly are collectively (they cannot be distinguished with that taxonomic sample) the second-best hypotheses with that dataset, with an AICc weight of only 0.1874 . The least-supported hypothesis with these data is the TH/DH with "branchiosaur" polyphyly.

Using the other postcranial dataset with only four bones (radius, ulna, ilium, and femur) but with more taxa (notably the branchiosaurid temnospondyl "Melanerpeton" humbergense) shows that intraspecific variation in the postcranial ossification sequences of Apateon do not significantly impact our assessment

Table 8. Support (AICC weights) for the various hypotheses about amphibian origins according to dataset 3 (see Table 1). Dataset 3 features seven appendicular characters (humerus, radius, ulna, ilium, femur, tibia and fibula) and 62 taxa, including several Paleozoic taxa (the temnospondyls Archegosaurus decheni and Micromelerpeton credneri, the lepospondyls Hyloplesion longicaudatum and Microbrachis pelikani, and the tristichopterid Eusthenopteron foordi) in addition to Apateon (two species, A. caducus and A. pedestris) and Sclerocephalus haeuseri. The Apateon sequences come from Obermoschel. Abbreviations, boldface and hypotheses as in Table 5, except that the TH and both variant of the $\mathrm{DH}$ become indistinguishable, but the phylogenetic position of the "branchiosaur" Micromelerpeton can be tested.

\begin{tabular}{llllll}
\hline Hypothesis & AIC & L & AICc & $\Delta_{i}$ AICc & wi(AICc) \\
\hline LH & -885.0 & 443.5 & -884.2 & 11.808 & $2.177 E^{-3}$ \\
TH, DH (branchiosaur monophyly) & -881.1 & 441.6 & -880.3 & 2.897 & 0.1874 \\
TH, DH (branchiosaur polyphyly) & -886.4 & 444.2 & -885.6 & 15.754 & $3.027 E^{-4}$ \\
PH1 & -888.5 & 445.3 & -887.7 & 8.341 & 0.01232 \\
PH2 & $\mathbf{- 8 9 6 . 9}$ & $\mathbf{4 4 9 . 4}$ & $\mathbf{- 8 9 6 . 1}$ & $\mathbf{0 . 0 0 0}$ & $\mathbf{0 . 7 9 7 8}$ \\
\hline
\end{tabular}


Table 9. Effect of the intraspecific variability in ossification sequences of Apateon on the support (AICc weight; best values in boldface) for the various hypotheses about amphibian origins. The dataset (number 4 Table 1) includes only four appendicular bones (radius, ulna, ilium, and femur) and 63 to 65 taxa but it allows testing the impact of intraspecific variability in ossification sequences in Apateon, which are documented in two localities (Erdesbach and Obermoschel). Because of the number of tests presented (15: five topologies $x$ three sets of sequences), only the AICc weights are given. In all tests, the following Paleozoic taxa are present: Sclerocephalus haeuseri, Archegosaurus decheni, "Melanerpeton" humbergense, Micromelerpeton credneri, Apateon (two species, A. caducus and A. pedestris) among temnospondyls, Hyloplesion longicaudatum and Microbrachis pelikani among lepospondyls, and the tristichopterid Eusthenopteron foordi. For abbreviations of the hypotheses, see Table 5.

\begin{tabular}{llll}
\hline Hypothesis & Erdesbach and Obermoschel & Erdesbach & Obermoschel \\
\hline LH & 0.21407 & 0.20169 & 0.22657 \\
TH, DH (branchiosaur monophyly) & 0.05492 & 0.05265 & 0.05532 \\
TH, DH (branchiosaur polyphyly) & 0.03713 & 0.04285 & 0.03342 \\
PH1 & 0.05653 & 0.05491 & 0.05638 \\
PH2 & $\mathbf{0 . 6 3 7 3 5}$ & $\mathbf{0 . 6 4 7 9 0}$ & $\mathbf{0 . 6 2 8 3 2}$ \\
\hline
\end{tabular}

of the support for various hypotheses. Whether both sequences of Apateon (from the Erdesbach and Obermoschel localities, which represent separate paleo-lakes) are included (treated as if they were distinct taxa, such as subspecies), or whether either one of these is used in isolation, the $\mathrm{PH} 2$ retains the highest support, with AICc weights of 0.62 to 0.65 . The LH is a distant second, at $0.20-0.23$, but still well ahead of the TH/DH and the $\mathrm{PH} 1$, which all receive AICc weights between 0.03 and 0.06 (Table 9).

\section{Discussion}

\section{Phylogenetic signal}

In his discussion of previous phylogenetic conclusions from ossification sequences (e.g., Schoch and Carroll, 2003), Anderson (2007) noted that ossification sequences seemed to abound in symplesiomorphies and in autapomorphies of terminal taxa, while potential synapomorphies were scarce. This pessimism was seemingly confirmed by Schoch (2006) in a paper that was published after Anderson's (2007) book chapter had gone to press: not only were many similarities in the cranial ossification sequences across Osteichthyes found to be symplesiomorphies, but a phylogenetic analysis of cranial ossification sequences did not recover Mammalia, Sauropsida, Amniota or Lissamphibia as monophyletic. Along with these results, Schoch (2006) dismissed another: the position of the temnospondyl Apateon caducus (the only included extinct taxon) outside the tetrapod crown-group, i.e. the lepospondyl hypothesis on lissamphibian origins (LH).

While ossification sequences alone may not provide enough data for a phylogenetic analysis, as shown by our results (Figs. 3, 4), there is clearly a phylogenetic signal because the taxa are not randomly scattered over the tree. Specifically, our datasets (with much larger taxon samples than in Schoch, 2006) fit some tree topologies much better than others. Both the tests using COMET and squared-change parsimony with random taxon reshuffling overwhelmingly support the presence of a strong phylogenetic signal in the cranial data; the null hypothesis of the absence of a phylogenetic signal can be rejected in both cases, given that it has a probability of $<10^{-97}$ for the cranial and $<10^{-4}$ for the appendicular dataset. We conclude that the cranial dataset contains a strong phylogenetic signal, and are therefore cautiously optimistic about future contributions of ossification sequences to phylogenetics. We are less optimistic 
about the appendicular sequence data, which both tests suggest contains less phylogenetic signal.

The sizable effect on nodal estimates and inferred heterochronies of intraspecific variation found by Sheil et al. (2014) in lissamphibians could raise doubts about the robustness of our findings. We have been able to incorporate infraspecific variability in only two terminal taxa (Apateon caducus and A. pedestris), but Apateon has played a prominent role in discussions about the significance of cranial ossification sequences on the origins of extant amphibians (Schoch and Carroll, 2003; Schoch, 2006; Germain and Laurin, 2009). Thus, incorporation of intraspecific variability in Apateon is presumably much more important than in extant taxa, even though variability in the latter would obviously add to the analysis and should be tackled in the future. The variability in Apateon should be exempt from two sources of artefactual variability in ossification sequences discussed by Sheil et al. (2014), namely the way in which the specimens were collected (there can be no lab-raised specimens in long-extinct taxa) and the fixing method used (in this case, fossilization under quite consistent taphonomic conditions). The finding that the results are very similar no matter whether we used the Apateon sequences from Erdesbach, Obermoschel, or both, we find very similar results (Table 9), is reassuring. In this case, intraspecific variation has negligible impact. However, future studies should attempt to assess the effect of more generalized incorporation of intraspecific variability (in a greater proportion of the OTUs).

Of course, these results do not preclude functional or developmental constraints from applying to the same data. This phenomenon has been documented, among other taxa, in urodeles, whose development has often been compared with that of temnospondyls (e.g., Schoch and Carroll, 2003; Schoch, 2006; Fröbisch et al., 2007; Germain and Laurin, 2009; Fröbisch et al., 2015). For instance, Vorobyeva and Hinchliffe (1996) documented the larval functional constraints linked to early forelimb use that may cause an early development of manual digits 1 and 2, compared with other tetrapods, as briefly discussed below. However, in the case of our seven cranial characters, there is no evidence of functional constraints. This is a little-investigated topic, but all these bones apparently form a single developmental module of the urodele skull (Laurin, 2004). For the appendicular data, functional constraints might explain the more subdued phylogenetic signal, but this will have to be determined by additional research.

The finding that the postcranial characters that we analyzed contain relatively little phylogenetic signal may raise doubts about the claims that have been made about the phylogenetic implications of other such data. Specifically, Carroll et al. (1999) stated that the neural arches ossify before the centra in frogs and temnospondyls, but not in salamanders, caecilians or lepospondyls. When it was found that the centra do ossify first in a few cryptobranchoid salamanders, Carroll (2007, p. 30) took this as "strong evidence that the most primitive crown-group salamanders had a sequence of vertebral development that is common to frogs and labyrinthodonts [including temnospondyls] (but distinct from that of lepospondyls)". In fact, apart from tail regeneration in Hyloplesion and Microbrachis (where the centra ossify before the neural arches: Olori, 2015; Fröbisch et al., 2015; Vos et al., 2018), only one incompletely ossified vertebral column (referred to Utaherpeton) is known of any putative lepospondyl. "In this specimen, [...] five neural arches [...] have ossified behind the most posterior centrum" (Carroll and Chorn, 1995, 40-41). Carroll's (2007, p. 85) claim that "the centra always ossified prior to the arches" in lepospondyls is therefore rather puzzling.

Fröbisch et al. (2007) and (2015) pointed out that the first two digital rays (digits, metapodials and distal carpals/tarsals) ossify before the others ("preaxial polarity") in salamanders and the temnospondyls Apateon, Micromelerpeton and Sclerocephalus, while the fourth ossifies first ("postaxial polarity") in amniotes, frogs and "probably" (Fröbisch et al., 2015, pp. 233, 234) the lepospondyls Microbrachis and 
Hyloplesion. This latter inference, however, is based only on a delay in the ossification of the fifth ray that is shared specifically with sauropsid amniotes (Olori, 2015). Ossification sequences (however partial) of the other four rays in any lepospondyl are currently limited to the tarsus of Batropetes, which clearly shows preaxial polarity (Glienke, 2015, fig. 60-S; Marjanović and Laurin, 2019), and that of the putative (but see Clack et al., 2019) lepospondyl Sauropleura, in which likewise the second distal tarsal ossified before all others (Marjanović and Laurin, 2019). Outside of temno- and lepospondyls, Marjanović and Laurin $(2013,2019)$ presented evidence that preaxial polarity is plesiomorphic, widespread and dependent on the use of the still developing limbs for locomotion, which would explain why it was independently lost in amniotes and frogs and reduced (the second ray still forms first, but the delays between the rays are much reduced so that all form nearly at the same time) in direct-developing salamanders as well as in the limb regeneration of terrestrial postmetamorphic salamanders (Kumar et al., 2015). It may be relevant here that the PH2 (Fig. 1f), favored by our appendicular data, groups exactly those sampled taxa in a clade that are known to have preaxial polarity in limb development. To sum up, neither our own analyses nor the previous works that we cited above demonstrated conclusively that ossification sequences of postcranial elements provide reliable clues about the origin of extant amphibians.

In contrast, we are reasonably confident about our results on the cranial ossification sequences. Given the phylogenetic signal we have found in our cranial datasets, we think that ossification sequence data should eventually be added to phenotypic datasets for analyses of tetrapod phylogeny. Indeed, an analysis of amniote phylogeny using data from organogenesis sequences (coded using event-pairing in Parsimov) already exists (Werneburg and Sánchez-Villagra, 2009). The usefulness of such data for phylogenetic inference was further tested, with encouraging results, by Laurin and Germain (2011), and the present analysis adds additional support for it.

\section{Indirect support for the lepospondyl hypothesis from temnospondyls}

The strong support for the lepospondyl hypothesis that we have found in cranial data is surprising because cranial ossification sequence data, especially those of the Permo-Carboniferous temnospondyl Apateon, have often been claimed to contradict the LH (lepospondyl hypothesis, Fig. 1d). Similarities between Apateon and extant urodeles, in particular the supposedly "primitive" hynobiid Ranodon, have often been emphasized (Schoch and Carroll, 2003; Schoch and Milner, 2004; Carroll, 2007; Schoch, 2014a). However, other studies have already raised doubts about some of these claims (e.g., Schoch, 2006; Anderson, 2007; Germain and Laurin, 2009). Schoch (2006) and Anderson (2007) concluded that most characters shared between Apateon and urodeles were plesiomorphies. Germain and Laurin (2009) also demonstrated that, far from being very similar to the ancestral urodele morphotype (contra Schoch and Carroll, 2003 or Carroll, 2007), the cranial ossification sequence of Apateon was statistically significantly different from that of the hypothetical last common ancestor of all urodeles (as suspected by Anderson, 2007). However, these earlier studies did not clearly show which of the various hypotheses on lissamphibian origins the ossification sequences of Apateon spp. - or the newly available partial sequence (Werneburg, 2018) of the phylogenetically distant temnospondyl Sclerocephalus - supported most. This is what we have attempted to do here.

Unfortunately, the development of lepospondyls is too poorly documented to be incorporated into the cranial analyses, but we included two lepospondyls in analyses of appendicular data. These analyses weakly favor a polyphyletic origin of extant amphibians, with both temno- and lepospondyls in the amphibian clade, a hypothesis that has not been advocated seriously for decades (Milner, 1993, fig. 5B) as 
far as we know. However, given the moderate phylogenetic signal in these data, we view these results with skepticism. Olori (2011), using event-pairing with Parsimov (Jeffery et al., 2005) and PGi (Harrison and Larsson, 2008), analyzed lepospondyl postcranial ossification sequences and concluded that support for the three hypotheses that she tested (TH/DH with two different positions for Micromelerpeton, and LH) did not differ significantly. By contrast, our analyses of the postcranial data indicate a stronger support for polyphyly ( $\mathrm{PH} 2$ ) than for the $\mathrm{TH} / \mathrm{DH}$, which is only a distant second (Table 8) or third (behind $\mathrm{PH} 2$ and $\mathrm{LH}$; Table 9) depending on the analyses. Olori (2011) performed no statistical test of phylogenetic signal of her data, though a related test (performing phylogenetic analyses on the data) yielded trees (Olori, 2011, fig. 5.5-5.7) that are largely incongruent with the established consensus, in which most large taxa (Mammalia, Testudines, Lissamphibia, etc.) are para- or polyphyletic. Olori's (2011) results, like ours, support the conclusion that the phylogenetic signal in postcranial ossification sequence data is low.

Given the current limitations in the availability of developmental data in Paleozoic stegocephalians, we hope to have demonstrated that cranial ossification sequences of amniotes, lissamphibians and temnospondyls provide support for the LH that is independent of the phylogenetic analyses of Laurin (1998), Pawley (2006, appendix 6) or Marjanović and Laurin (2009, 2019). This independence is important because the cranial ossification sequence data cannot rival the morphological data in terms of data availability, simply because growth sequences of extinct taxa are rare (Sánchez-Villagra, 2012), but having a fairly independent line of evidence to investigate a major evolutionary problem is clearly advantageous. We hope that the modest methodological progress made in this study will stimulate the search for fossilized ontogenies (Cloutier, 2010; Sánchez-Villagra, 2010).

\section{Acknowledgements}

Jennifer Olori, two anonymous reviewers and the Recommender Robert Asher made helpful comments that improved this paper. D. M. would further like to thank Ralf Werneburg for an electronic reprint of his 2018 paper, Nadia Fröbisch for discussion of limb development in salamanders, and Daniel Field for discussion of molecular divergence times and the fossil record.

\section{Additional information}

\section{Funding}

This work was supported by the CNRS (Centre National de la Recherche Scientifique) and the French Ministry of Research (unnumbered recurring grants to the CR2P, for ML).

\section{Competing interests}

The authors declare that they have no personal or financial conflict of interest relating to the content of this study. ML is a Recommender for PCI Paleo. 


\section{Author contributions}

ML designed the study, supervised the data collection, analyzed the data and wrote much of the draft; OL collected most of the ossification sequence data; DM added data to the database (mostly of Paleozoic taxa), updated the timetrees, participated in the writing, and drafted Figure 1.

\section{Data availability}

All data used in this study are available as Supplementary material (see below)

\section{Supplementary information}

Data matrices and trees used in this analysis can be downloaded in NEXUS format for Mesquite from: https://www.biorxiv.org/content/10.1101/352609v3.supplementary-material.

\section{References}

Anderson DR and Burnham KP (2002). Avoiding pitfalls when using information-theoretic methods. The Journal of Wildlife Management 66, 912-918.

Anderson JS (2007). Incorporating ontogeny into the matrix: a phylogenetic evaluation of developmental evidence for the origin of modern amphibians. In: Major Transitions in Vertebrate Evolution. Ed. by Anderson JS and Sues HD. Bloomington, Indiana, USA: Indiana University Press, pp. 182-227.

Anderson JS, Reisz RR, Scott D, Fröbisch NB, and Sumida SS (2008). A stem batrachian from the Early Permian of Texas and the origin of frogs and salamanders. Nature 453, 515-518. DoI: 10.1038 / nature06865.

Anderson JS, Carroll RL, and Rowe TB (2003). New information on Lethiscus stocki (Tetrapoda: Lepospondyli: Aistopoda) from high-resolution computed tomography and a phylogenetic analysis of Aistopoda. Canadian Journal of Earth Sciences 40, 1071-1083. DoI: 10.1139/e03-023.

Berv JS and Field DJ (2018). Genomic signature of an avian lilliput effect across the K-Pg extinction. Systematic Biology 67, 1-13. DOI: 10.1093/sysbio/syx064.

Bokma F, Godinot M, Maridet O, Ladevèze S, Costeur L, Solé F, Gheerbrant E, Peigné S, Jacques F, and Laurin M (2016). Testing for Depéret's Rule (body size increase) in mammals using combined extinct and extant data. Systematic Biology 65, 98-108. DoI: 10.1093/sysbio/syv075.

Bolt JR (1969). Lissamphibian origins: possible protolissamphibian from the Lower Permian of Oklahoma. Science 166, 888-891. DOI: 10.1126/science.166.3907.888.

Bossuyt F and Roelants K (2009). Frogs and toads (Anura). In: The Timetree of Life. Ed. by Hedges SB and Kumar S. New York, USA: Oxford University Press, pp. 357-364.

Brandley MC, Schmitz A, and Reeder TW (2005). Partitioned Bayesian analyses, partition choice, and the phylogenetic relationships of scincid lizards. Systematic Biology 54, 373-390. DoI: 10.1080/ 10635150590946808.

Carpenter DK, Falcon-Lang HJ, Benton MJ, and Grey M (2015). Early Pennsylvanian (Langsettian) fish assemblages from the Joggins Formation, Canada, and their implications for palaeoecology and palaeogeography. Palaeontology 58, 661-690. DoI: 10.1111/pala.12164.

Carroll RL (2001). The origin and early radiation of terrestrial vertebrates. Journal of Paleontology 75 , 1202-1213. DoI: $10.1017 /$ S0022336000017248. 
Carroll RL (2007). The Palaeozoic ancestry of salamanders, frogs and caecilians. Zoological Journal of the Linnean Society 150 (suppl_1), 1-140. DoI: 10.1111/j.1096-3642.2007.00246.x.

Carroll RL and Chorn J (1995). Vertebral development in the oldest microsaur and the problem of "lepospondyl" relationships. Journal of Vertebrate Paleontology 15, 37-56. DOI: 10.1080/02724634.1995. 10011206.

Carroll RL and Currie PJ (1975). Microsaurs as possible apodan ancestors. Zoological Journal of the Linnean Society 57, 229-247. DoI: 10.1111/j.1096-3642.1975.tb00817.x.

Carroll RL and Holmes R (1980). The skull and jaw musculature as guides to the ancestry of salamanders. Zoological Journal of the Linnean Society 68, 1-40. DoI: 10.1111/j.1096-3642.1980.tb01916.x.

Carroll RL, Kuntz A, and Albright K (1999). Vertebral development and amphibian evolution. Evolution \& Development 1, 36-48. DoI: 10.1111/j.1525-142X.1999.t01-2-.X.

Clack JA, Ruta M, Milner AR, Marshall JEA, Smithson TR, and Smithson KZ (2019). Acherontiscus caledoniae: the earliest heterodont and durophagous tetrapod. Royal Society open science 6, 182087. DOI: 10.1098/ rsos. 182087.

Cloutier R (2010). The fossil record of fish ontogenies: Insights into developmental patterns and processes. Seminars in Cell \& Developmental Biology 21, 400-413. DoI: 10.1016/j.semcdb.2009.11.004.

Cope ED (1888). On the intercentrum of the terrestrial Vertebrata. Transactions of the American Philosophical Society $16,243-253$.

Cote S, Carroll R, Cloutier R, and Bar-Sagi L (2002). Vertebral development in the Devonian sarcopterygian fish Eusthenopteron foordi and the polarity of vertebral evolution in non-amniote tetrapods. Journal of Vertebrate Paleontology 22, 487-502. DOI: 10.1671/0272-4634(2002)022[0487:VDITDS]2.0.CO;2.

Criswell KE (2015). The comparative osteology and phylogenetic relationships of African and South American lungfishes (Sarcopterygii: Dipnoi). Zoological Journal of the Linnean Society 174, 801-858. DOI: 10.1111/zoj.12255.

Danto M, Witzmann F, Kamenz SK, and Fröbisch NB (2019). How informative is vertebral development for the origin of lissamphibians? Journal of Zoology 307, 292-305. Dol: 10.1111/jzo.12648.

Davies TW, Bell MA, Goswami A, and Halliday TJD (2017). Completeness of the eutherian mammal fossil record and implications for reconstructing mammal evolution through the Cretaceous/Paleogene mass extinction. Paleobiology 43, 521-536. DoI: 10.1017/pab.2017.20.

Eldredge N and Gould SJ (1972). Punctuated equilibria: an alternative to phyletic gradualism. In: Models in Paleobiology. Ed. by Schopf TJM. San Francisco, USA: Freeman, Cooper \& Company, pp. 82-115.

Feng YJ, Blackburn DC, Liang D, Hillis DM, Wake DB, Cannatella DC, and Zhang P (2017). Phylogenomics reveals rapid, simultaneous diversification of three major clades of Gondwanan frogs at the Cretaceous-Paleogene boundary. Proceedings of the National Academy of Sciences 114, E5864-E5870. DOI: 10.1073/pnas.1704632114.

Fröbisch NB, Bickelmann C, Olori JC, and Witzmann F (2015). Deep-time evolution of regeneration and preaxial polarity in tetrapod limb development. Nature 527, 231-234. DOI: 10.1038/nature15397.

Fröbisch NB, Carroll RL, and Schoch RR (2007). Limb ossification in the Paleozoic branchiosaurid Apateon (Temnospondyli) and the early evolution of preaxial dominance in tetrapod limb development. Evolution \& Development 9, 69-75. Dol: 10.1111/j.1525-142X.2006.00138.x.

Germain D and Laurin M (2009). Evolution of ossification sequences in salamanders and urodele origins assessed through event-pairing and new methods. Evolution \& Development 11, 170-190. DoI: 10.1111/ j.1525-142X.2009.00318.x.

Glienke S (2015). Two new species of the genus Batropetes (Tetrapoda, Lepospondyli) from the Central European Rotliegend (basal Permian) in Germany. Journal of Vertebrate Paleontology 35, e918041. Dol: 10.1080/02724634.2014.918041. 
Gonzalez J, Düttmann H, and Wink M (2009). Phylogenetic relationships based on two mitochondrial genes and hybridization patterns in Anatidae. Journal of Zoology 279, 310-318. DOI: 10.1111/j.14697998.2009.00622.x.

Halliday TJD, Upchurch P, and Goswami A (2017). Resolving the relationships of Paleocene placental mammals. Biological Reviews 92, 521-550. DoI: 10.1111/brv.12242.

Halliday TJD, Upchurch P, and Goswami A (2016). Eutherians experienced elevated evolutionary rates in the immediate aftermath of the Cretaceous-Palaeogene mass extinction. Proceedings of the Royal Society B: Biological Sciences 283, 20153026. DOI: 10.1098/rspb.2015.3026.

Harrington SM, Harrison LB, and Sheil CA (2013). Ossification sequence heterochrony among amphibians. Evolution \& Development 15, 344-364. DoI: 10.1111/ede.12043.

Harrison LB and Larsson HCE (2008). Estimating evolution of temporal sequence changes: a practical approach to inferring ancestral developmental sequences and sequence heterochrony. Systematic Biology 57, 378-387. DOI: 10.1080/10635150802164421.

Hugall AF, Foster R, and Lee MSY (2007). Calibration choice, rate smoothing, and the pattern of tetrapod diversification according to the long nuclear gene RAG-1. Systematic Biology 56, 543-563. DoI: 10.1080/ 10635150701477825.

Hugi J, Hutchinson MN, Koyabu D, and Sánchez-Villagra MR (2012). Heterochronic shifts in the ossification sequences of surface- and subsurface-dwelling skinks are correlated with the degree of limb reduction. Zoology 115, 188-198. DOI: 10.1016/j.zool.2011.10.003.

Irisarri I, Baurain D, Brinkmann H, Delsuc F, Sire JY, Kupfer A, Petersen J, Jarek M, Meyer A, Vences M, and Philippe $H$ (2017). Phylotranscriptomic consolidation of the jawed vertebrate timetree. Nature Ecology \& Evolution 1, 1370-1378. DoI: 10.1038/s41559-017-0240-5.

Jeffery JE, Bininda-Emonds ORP, Coates MI, and Richardson MK (2005). A new technique for identifying sequence heterochrony. Systematic Biology 54, 230-240. DOI: 10.1080/10635150590923227.

Jetz W and Pyron RA (2018). The interplay of past diversification and evolutionary isolation with present imperilment across the amphibian tree of life. Nature Ecology \& Evolution 2, 850-858. DoI: 10.1038/ s41559-018-0515-5.

Josse S, Moreau T, and Laurin M (2006). Stratigraphic too/s for Mesquite. Version 1.0. URL: http://mesquiteproject. org/packages/stratigraphicTools/.

Koyabu D, Werneburg I, Morimoto N, Zollikofer CPE, Forasiepi AM, Endo H, Kimura J, Ohdachi SD, Truong Son N, and Sánchez-Villagra MR (2014). Mammalian skull heterochrony reveals modular evolution and a link between cranial development and brain size. Nature Communications 5, 3625. DoI: 10.1038/ ncomms4625.

Kumar A, Gates PB, Czarkwiani A, and Brockes JP (2015). An orphan gene is necessary for preaxial digit formation during salamander limb development. Nature Communications 6, 8684. DOI: 10.1038/ ncomms9684.

Laurin M (1998). The importance of global parsimony and historical bias in understanding tetrapod evolution. Part I. Systematics, middle ear evolution and jaw suspension. Annales des Sciences Naturelles - Zoologie et Biologie Animale 19, 1-42. DoI: 10.1016/S0003-4339(98)80132-9.

Laurin M (2004). The evolution of body size, Cope's Rule and the origin of amniotes. Systematic Biology 53, 594-622. DOI: 10.1080/10635150490445706.

Laurin M (2014). Assessment of modularity in the urodele skull: An exploratory analysis using ossification sequence data. Journal of Experimental Zoology Part B: Molecular and Developmental Evolution 322, 567-585. DoI: 10.1002/jez.b.22575.

Laurin M and Germain D (2011). Developmental characters in phylogenetic inference and their absolute timing information. Systematic Biology 60, 630-644. DoI: 10.1093/sysbio/syr024. 
Laurin M and Piñeiro GH (2017). A reassessment of the taxonomic position of mesosaurs, and a surprising phylogeny of early amniotes. Frontiers in Earth Science 5, 88. DoI: 10.3389/feart.2017.00088.

Leblanc J and Cloutier R (2005). Developmental modularity and saltatory ontogeny in the Late Devonian osteolepiform Eusthenopteron foordi. In: Leblanc J. Précisions sur l'anatomie de l'ostéolépiforme Eusthenopteron foordi du Dévonien supérieur de Miguasha, Québec. Rimouski, Quebec, Canada: Mémoire de maîtrise (MSc thesis), Université du Québec, pp. 32-84. eprint: http://semaphore.uqar.ca/id/eprint/ 283.

Lecompte E, Aplin K, Denys C, Catzeflis F, Chades M, and Chevret P (2008). Phylogeny and biogeography of African Murinae based on mitochondrial and nuclear gene sequences, with a new tribal classification of the subfamily. BMC Evolutionary Biology 8, 199. Dol: 10.1186/1471-2148-8-199.

Lee C, Blay S, Mooers AØ, Singh A, and Oakley TH (2006). CoMET: A Mesquite package for comparing models of continuous character evolution on phylogenies. Evolutionary Bioinformatics 2, 193-196. DOI: 10.1177/117693430600200022. URL: https://labs.eemb.ucsb.edu/oakley/todd/software/co.

Lu T, Zhu M, Yi C, Si C, Yang C, and Chen H (2017). Complete mitochondrial genome of the gray red-backed vole (Myodes rufocanus) and a complete estimate of the phylogenetic relationships in Cricetidae. Mitochondrial DNA Part A 28, 62-64. DOI: 10.3109/19401736.2015.1110799.

Maddin HC, Jenkins FA, and Anderson JS (2012). The braincase of Eocaecilia micropodia (Lissamphibia, Gymnophiona) and the origin of caecilians. PLOS ONE 7, e50743. DOI: 10.1371/journal.pone.0050743.

Maddison WP (1991). Squared-change parsimony reconstructions of ancestral states for continuousvalued characters on a phylogenetic tree. Systematic Biology 40, 304-314. DOI: 10.1093/sysbio/40.3.304.

Maddison WP and Maddison DR (2018). Mesquite: a modular system for evolutionary analysis. Version 3.6. URL: http://mesquite.wikispaces.com/.

Mann A, Pardo JD, and Maddin HC (2019). Infernovenator steenae, a new serpentine recumbirostran from the 'Mazon Creek' Lagerstätte further clarifies lysorophian origins. Zoological Journal of the Linnean Society 187, 506-517. DoI: 10.1093/zoolinnean/zlz026.

Marjanović D and Laurin M (2007). Fossils, molecules, divergence times, and the origin of lissamphibians. Systematic Biology 56, 369-388. DoI: 10.1080/10635150701397635.

Marjanović D and Laurin M (2008). Assessing confidence intervals for stratigraphic ranges of higher taxa: the case of Lissamphibia. Acta Palaeontologica Polonica 53, 413-432. DOI: 10.4202/app.2008.0305.

Marjanović D and Laurin M (2009). The origin(s) of modern amphibians: a commentary. Evolutionary Biology 36, 336-338. DoI: 10.1007/s11692-009-9065-8.

Marjanović D and Laurin M (2013). The origin(s) of extant amphibians: a review with emphasis on the "lepospondyl hypothesis". Geodiversitas 35, 207-272. DoI: 10.5252/g2013n1a8.

Marjanović D and Laurin M (2014). An updated paleontological timetree of lissamphibians, with comments on the anatomy of Jurassic crown-group salamanders (Urodela). Historical Biology 26, 535-550. DOI: 10.1080/08912963.2013.797972.

Marjanović D and Laurin M (2019). Phylogeny of Paleozoic limbed vertebrates reassessed through revision and expansion of the largest published relevant data matrix. PeerJ 6, e5565. DoI: 10.7717/peerj.5565.

Maxwell EE, Harrison LB, and Larsson HC (2010). Assessing the phylogenetic utility of sequence heterochrony: evolution of avian ossification sequences as a case study. Zoology 113, 57-66. DOI: 10.1016/j.zool.2009.06.002.

Meredith RW, Janecka JE, Gatesy J, Ryder OA, Fisher CA, Teeling EC, Goodbla A, Eizirik E, Simao TLL, Stadler T, Rabosky DL, Honeycutt RL, Flynn JJ, Ingram CM, Steiner C, Williams TL, Robinson TJ, Burk-Herrick A, Westerman M, Ayoub NA, Springer MS, and Murphy WJ (2011). Impacts of the Cretaceous terrestrial revolution and KPg extinction on mammal diversification. Science 334, 521-524. DOI: 10.1126/science. 1211028 . 
Milner AR (1993). The Paleozoic relatives of lissamphibians. Herpetological Monographs 7, 8-27. DoI: $10.2307 / 1466948$.

Ogg JG, Ogg GM, and Gradstein FM (2016). A Concise Geologic Time Scale: 2016. Amsterdam, The Netherlands: Elsevier. ISBN: 978-0-444-59468-6.

Olori JC (2011). The evolution of skeletal development in early tetrapods: anatomy and ontogeny of microsaurs (Lepospondyli). PhD thesis. Austin, Texas, USA: University of Texas. eprint: http://hdl. handle.net/2152/ETD-UT-2011-05-3535.

Olori JC (2013). Ontogenetic sequence reconstruction and sequence polymorphism in extinct taxa: an example using early tetrapods (Tetrapoda: Lepospondyli). Paleobiology 39, 400-428. DoI: 10.1666/ 12031.

Olori JC (2015). Skeletal morphogenesis of Microbrachis and Hyloplesion (Tetrapoda: Lepospondyli), and implications for the developmental patterns of extinct, early tetrapods. PLOS ONE 10, e0128333. DOI: 10.1371/journal.pone.0128333.

Pardo JD, Carter A, Lennie K, Sallan LC, and Anderson JS (2018). New $\mu$ CT data on nectrideans reveals unappreciated complexities in early tetrapod evolution. Vertebrate Anatomy Morphology Palaeontology 5 (CSVP 2018 Abstracts), 41. DOI: 10.18435/vamp29338.

Pardo JD, Small BJ, and Huttenlocker AK (2017a). Stem caecilian from the Triassic of Colorado sheds light on the origins of Lissamphibia. Proceedings of the National Academy of Sciences 114, E5389-E5395. DOI: 10.1073/pnas.1706752114.

Pardo JD, Szostakiwskyj M, Ahlberg PE, and Anderson JS (2017b). Hidden morphological diversity among early tetrapods. Nature 546, 642-645. DoI: 10.1038/nature22966.

Parsons TS and Williams EE (1962). The teeth of amphibia and their relation to amphibian phylogeny. Journal of Morphology 110, 375-389. DOI: 10.1002/jmor.1051100305.

Parsons TS and Williams EE (1963). The relationships of the modern Amphibia: A re-examination. The Quarterly Review of Biology 38, 26-53. DoI: 10.1086/403748.

Pawley K (2006). The postcranial skeleton of temnospondyls (Tetrapoda: Temnospondyli). PhD thesis. Melbourne, Australia: La Trobe University. eprint: http://hdl.handle.net/1959.9/405644.

Phillips MJ and Fruciano C (2018). The soft explosive model of placental mammal evolution. BMC Evolutionary Biology 18, 104. DOI: 10.1186/s12862-018-1218-x.

Poe S (2006). Test of von Baer's law of the conservation of early development. Evolution 60, 2239-2245. DOI: 10.1111/j.0014-3820.2006.tb01861.x.

Pons JM, Hassanin A, and Crochet PA (2005). Phylogenetic relationships within the Laridae (Charadriiformes: Aves) inferred from mitochondrial markers. Molecular Phylogenetics and Evolution 37, 686-699. DOI: 10.1016/j.ympev.2005.05.011.

Prum RO, Berv JS, Dornburg A, Field DJ, Townsend JP, Lemmon EM, and Lemmon AR (2015). A comprehensive phylogeny of birds (Aves) using targeted next-generation DNA sequencing. Nature 526, 569-573. DOI: 10.1038/nature15697.

Pyron RA (2014). Biogeographic analysis reveals ancient continental vicariance and recent oceanic dispersal in amphibians. Systematic Biology 63, 779-797. Dol: 10.1093/sysbio/syu042.

Rabosky DL, Donnellan SC, Grundler M, and Lovette IJ (2014). Analysis and visualization of complex macroevolutionary dynamics: an example from Australian scincid lizards. Systematic Biology 63, 610627. DoI: 10.1093/sysbio/syu025.

Reeder TW (2003). A phylogeny of the Australian Sphenomorphus group (Scincidae: Squamata) and the phylogenetic placement of the crocodile skinks (Tribolonotus): Bayesian approaches to assessing congruence and obtaining confidence in maximum likelihood inferred relationships. Molecular Phylogenetics and Evolution 27, 384-397. DOI: 10.1016/S1055-7903(02)00448-7. 
Rineau V, Grand A, Zaragüeta R, and Laurin M (2015). Experimental systematics: sensitivity of cladistic methods to polarization and character ordering schemes. Contributions to Zoology 84, 129-148. DOI: 10.1163/18759866-08402003.

Rineau V, Zaragüeta R, and Laurin M (2018). Impact of errors on cladistic inference: Simulation-based comparison between parsimony and three-taxon analysis. Contributions to Zoology 87, 25-40. DOI: 10.1163/18759866-08701003.

Ruta M and Coates MI (2007). Dates, nodes and character conflict: Addressing the lissamphibian origin problem. Journal of Systematic Palaeontology 5, 69-122. DOI: 10.1017/S1477201906002008.

Sánchez-Villagra MR (2010). Contributions on fossilised ontogenies: The rock record of vertebrate development. Seminars in Cell \& Developmental Biology 21, 399. Dol: 10.1016/j.semcdb.2009.12.001.

Sánchez-Villagra MR (2012). Embryos in deep time: the rock record of biological development. Berkeley, CA, US: University of California Press. 256 pp. ISBN: 978-0-520-27193-7.

Schneider JW, Werneburg R, Rößler R, Voigt S, and Scholze F (2015). Example for the description of basins in the CPT nonmarine-marine correlation chart - Thuringian Forest Basin, East Germany. Permophiles 61, 29-35.

Schoch RR (2002). The early formation of the skull in extant and Paleozoic amphibians. Paleobiology 28, 278-296. DOI: 10.1666/0094-8373(2002)028<0278:TEFOTS>2.0.CO;2.

Schoch RR (2004). Skeleton formation in the Branchiosauridae: a case study in comparing ontogenetic trajectories. Journal of Vertebrate Paleontology 24, 309-319. DoI: 10.1671/1950.

Schoch RR (2006). Skull ontogeny: developmental patterns of fishes conserved across major tetrapod clades. Evolution \& Development 8, 524-536. DoI: 10.1111/j.1525-142X.2006.00125.x.

Schoch RR (2014a). Amphibian skull evolution: The developmental and functional context of simplification, bone loss and heterotopy. Journal of Experimental Zoology Part B: Molecular and Developmental Evolution 322, 619-630. Dol: 10.1002/jez.b.22599.

Schoch RR (2014b). First evidence of the branchiosaurid temnospondyl Leptorophus in the Early Permian of the Saar-Nahe Basin (SW Germany). Neues Jahrbuch für Geologie und Paläontologie - Abhandlungen 272, 225-236. DOI: 10.1127/0077-7749/2014/0401.

Schoch RR (2019). The putative lissamphibian stem-group: phylogeny and evolution of the dissorophoid temnospondyls. Journal of Paleontology 93, 137-156. DoI: 10.1017/jpa.2018.67.

Schoch RR and Carroll RL (2003). Ontogenetic evidence for the Paleozoic ancestry of salamanders. Evolution and Development 5, 314-324. DoI: 10.1046/j.1525-142X.2003.03038.x.

Schoch RR and Milner AR (2004). Structure and implications of theories on the origin of lissamphibians. In: Recent Advances in the Origin and Early Radiation of Vertebrates. Ed. by Arratia G, Wilson MVH, and Cloutier R. Munich, Germany: Dr. Friedrich Pfeil, pp. 345-377.

Schulmeister S and Wheeler WC (2004). Comparative and phylogenetic analysis of developmental sequences. Evolution and Development 6, 50-57. DoI: 10.1111/j.1525-142X.2004.04005.x.

Sheil CA, Jorgensen M, Tulenko F, and Harrington S (2014). Variation in timing of ossification affects inferred heterochrony of cranial bones in Lissamphibia. Evolution \& Development 16, 292-305. DOI: 10.1111/ede.12092.

Sigurdsen T and Green DM (2011). The origin of modern amphibians: a re-evaluation. Zoological Journal of the Linnean Society 162, 457-469. DOI: 10.1111/j.1096-3642.2010.00683.x.

Skawiński T and Borczyk B (2017). Evolution of developmental sequences in lepidosaurs. PeerJ 5, e3262. DoI: 10.7717/peerj.3262.

Spiekman SNF and Werneburg I (2017). Patterns in the bony skull development of marsupials: high variation in onset of ossification and conserved regions of bone contact. Scientific Reports 7, 43197. DOI: $10.1038 /$ srep43197. 
Steen MC (1938). On the fossil Amphibia from the gas coal of Nýrrrany and other deposits in Czechoslovakia. Proceedings of the Zoological Society of London 108, 205-283. DoI: 10.1111/j.1096-3642.1938.tb00027.x.

Sterli J, Fuente MS de la, and Rougier GW (2018). New remains of Condorchelys antiqua (Testudinata) from the Early-Middle Jurassic of Patagonia: anatomy, phylogeny, and paedomorphosis in the early evolution of turtles. Journal of Vertebrate Paleontology 38, e1480112. DoI: 10.1080/02724634.2018. 1480112

Sterli J, Pol D, and Laurin M (2013). Incorporating phylogenetic uncertainty on phylogeny-based palaeontological dating and the timing of turtle diversification. Cladistics 29, 233-246. DoI: 10.1111/j.10960031.2012.00425.x.

Swofford DL (2019). PAUP*: Phylogenetic Analysis Using Parsimony (*and other methods). Version 4.0a165 (Expired). URL: http://phylosolutions.com/paup-test/.

Tarver JE, Reis M dos, Mirarab S, Moran RJ, Parker S, O'Reilly JE, King BL, O'Connell MJ, Asher RJ, Warnow T, Peterson KJ, Donoghue PC, and Pisani D (2016). The interrelationships of placental mammals and the limits of phylogenetic inference. Genome Biology and Evolution 8, 330-344. DoI: 10.1093/gbe/evv261.

Vorobyeva El and Hinchliffe JR (1996). Developmental pattern and morphology of Salamendrella keyserlingii limbs (Amphibia, Hynobiidae) including some evolutionary aspects. Russian Journal of Herpetology 1 , 68-81.

Vos W van der, Witzmann F, and Fröbisch NB (2018). Tail regeneration in the Paleozoic tetrapod Microbrachis pelikani and comparison with extant salamanders and squamates. Journal of Zoology 304, 34-44. DoI: 10.1111/jzo.12516.

Wagenmakers EJ and Farrell S (2004). AIC model selection using Akaike weights. Psychonomic Bulletin \& Review 11, 192-196. DoI: 10.3758/BF03206482.

Wang N, Kimball RT, Braun EL, Liang B, and Zhang Z (2013). Assessing phylogenetic relationships among Galliformes: a multigene phylogeny with expanded taxon sampling in Phasianidae. PLOS ONE 8 , e64312. DoI: 10.1371/journal.pone.0064312.

Watson DMS (1940). The origin of frogs. Transactions of the Royal Society of Edinburgh 60, 195-231. Dol: $10.1017 /$ S0080456800017877.

Weisbecker V (2011). Monotreme ossification sequences and the riddle of mammalian skeletal development. Evolution 65, 1323-1335. DOI: 10.1111/j.1558-5646.2011.01234.x.

Weisbecker V and Mitgutsch C (2010). A large-scale survey of heterochrony in anuran cranial ossification patterns. Journal of Zoological Systematics and Evolutionary Research 48, 332-347. DOI: 10.1111/j.14390469.2010.00570.x.

Werneburg I and Geiger M (2017). Ontogeny of domestic dogs and the developmental foundations of carnivoran domestication. Journal of Mammalian Evolution 24, 323-343. DOI: 10.1007/s10914-0169346-9.

Werneburg I and Sánchez-Villagra MR (2009). Timing of organogenesis support basal position of turtles in the amniote tree of life. BMC Evolutionary Biology 9, 82. DoI: 10.1186/1471-2148-9-82.

Werneburg R (2018). Earliest 'nursery ground' of temnospondyl amphibians in the Permian. Semana 32, 3-42.

Witzmann F (2006). Developmental patterns and ossification sequence in the Permo-Carboniferous temnospondyl Archegosaurus decheni (Saar-Nahe Basin, Germany). Journal of Vertebrate Paleontology 26, 7-17. DOI: 10.1671/0272-4634(2006)26[7:DPAOSI]2.0.CO;2.

Zhang P, Zhou H, Chen YQ, Liu YF, and Qu LH (2005). Mitogenomic perspectives on the origin and phylogeny of living amphibians. Systematic Biology 54, 391-400. DOI: 10.1080/10635150590945278.

Zhuang L, Bluteau G, and Trueb B (2015). Phylogenetic analysis of receptor FgfrL1 shows divergence of the C-terminal end in rodents. Comparative Biochemistry and Physiology Part B: Biochemistry and Molecular Biology 186, 43-50. DoI: 10.1016/j.cbpb.2015.04.009. 
bioRxiv preprint first posted online Jun. 20, 2018; doi: http://dx.doi.org/10.1101/352609. The copyright holder for this preprint

(which was not peer-reviewed) is the author/funder, who has granted bioRxiv a license to display the preprint in perpetuity.

All rights reserved. No reuse allowed without permission.

\section{Appendix}

\section{Sources of data for ossification sequences}

Empty cells indicate that these data are unavailable. Three methods were examined, and we used the one for which most data were available (position in the ossification sequence, last column).

\begin{tabular}{|c|c|c|c|}
\hline \multirow[t]{2}{*}{ Taxa } & \multicolumn{3}{|c|}{ Standardization method (data type used) } \\
\hline & Ontogenetic stages & Snout-vent length $(\mathrm{mm})$ & Ossification sequence position \\
\hline \multicolumn{4}{|l|}{ Actinopterygii } \\
\hline Amia calva & & Grande and Bemis (1998) & Grande and Bemis (1998) \\
\hline Clarias gariepinus & & Adriaens and Verraes (1998) & Adriaens and Verraes (1998) \\
\hline Danio rerio & & Cubbage and Mabee (1996) & Cubbage and Mabee (1996) \\
\hline Oryzias latipes & Langille and Hall (1987) & & \\
\hline \multicolumn{4}{|l|}{ Tristichopteridae } \\
\hline Eusthenopteron foordi & & $\begin{array}{l}\text { Cote et al. (2002); Leblanc and Cloutier } \\
\text { (2005) }\end{array}$ & $\begin{array}{l}\text { Cote et al. (2002); Leblanc and Cloutier } \\
\text { (2005) }\end{array}$ \\
\hline \multicolumn{4}{|l|}{ Temnospondyli } \\
\hline Archegosaurus decheni & & Witzmann (2006) & Witzmann (2006) \\
\hline Apateon caducus (Erdesbach) & Schoch (2004) & Schoch (2004) & Schoch (2004) \\
\hline Apateon caducus (Obermoschel) & & Werneburg (2018) & Werneburg (2018) \\
\hline Apateon pedestris (Erdesbach) & Schoch (2004) & & Schoch (2004) \\
\hline Apateon pedestris (Obermoschel) & & Werneburg (2018) & Werneburg (2018) \\
\hline "Melanerpeton" humbergense & Schoch (2004) & & Schoch (2004) \\
\hline Micromelerpeton credneri & & $\begin{array}{l}\text { Boy (1995); Witzmann and Pfret- } \\
\text { zschner (2003); Lillich and Schoch } \\
\text { (2007); Schoch (2009) }\end{array}$ & $\begin{array}{l}\text { Boy (1995); Witzmann and Pfret } \\
\text { zschner (2003); Lillich and Schoch } \\
\text { (2007); Schoch (2009) }\end{array}$ \\
\hline Sclerocephalus haeuseri & $\begin{array}{l}\text { Lohmann and Sachs (2001); Schoch } \\
\text { (2003); Schoch and Witzmann (2009); } \\
\text { Werneburg (2018) }\end{array}$ & $\begin{array}{l}\text { Lohmann and Sachs (2001); Schoch } \\
\text { (2003); Schoch and Witzmann (2009); } \\
\text { Werneburg (2018) }\end{array}$ & $\begin{array}{l}\text { Lohmann and Sachs (2001); Schoch } \\
\text { (2003); Schoch and Witzmann (2009); } \\
\text { Werneburg (2018) }\end{array}$ \\
\hline \multicolumn{4}{|l|}{ Lepospondyli } \\
\hline Hyloplesion longicaudatum & & Olori (2013) & Olori (2013) \\
\hline Microbrachis pelikani & & Olori (2013) & Olori (2013) \\
\hline \multicolumn{4}{|l|}{ Gymnophiona } \\
\hline Gegeneophis ramaswamii & Müller et al. (2005) & & Harrington et al. (2013) \\
\hline Hypogeophis rostratus & Müller (2006) & & Harrington et al. (2013) \\
\hline \multicolumn{4}{|l|}{ Urodela } \\
\hline Aneides lugrubis & & Wake et al. (1983) & Wake et al. (1983) \\
\hline Ambystoma macrodactylum & & & Harrington et al. (2013) \\
\hline Ambystoma maculatum & & & Harrington et al. (2013) \\
\hline Ambystoma mexicanum & & Laurin and Germain (2011) & Harrington et al. (2013) \\
\hline Ambystoma talpoideum & Reilly (1987) & Reilly (1987) & Reilly (1987) \\
\hline Ambystoma texanum & & Laurin and Germain (2011) & Harrington et al. (2013) \\
\hline Ambystoma tigrinum & & & Harrington et al. (2013) \\
\hline Amphiuma means & & & Harrington et al. (2013) \\
\hline Andrias japonicus & & & Harrington et al. (2013) \\
\hline Bolitoglossa subpalmata & & & Ehmcke and Clemen (2000) \\
\hline Dicamptodon tenebrosus & & & Harrington et al. (2013) \\
\hline
\end{tabular}

Continued on next page. 
bioRxiv preprint first posted online Jun. 20, 2018; doi: http://dx.doi.org/10.1101/352609. The copyright holder for this preprint

(which was not peer-reviewed) is the author/funder, who has granted bioRxiv a license to display the preprint in perpetuity.

All rights reserved. No reuse allowed without permission.

Continued from previous page.

\begin{tabular}{|c|c|c|c|}
\hline \multirow[t]{2}{*}{ Taxa } & \multicolumn{3}{|c|}{ Standardization method (data type used) } \\
\hline & Ontogenetic stages & Snout-vent length (mm) & Ossification sequence position \\
\hline Eurycea bislineata & & & Harrington et al. (2013) \\
\hline Gyrinophilus porphyriticus & & & Harrington et al. (2013) \\
\hline Hemidactylium scutatum & & & Harrington et al. (2013) \\
\hline Lissotriton vulgaris & & Laurin and Germain (2011) & Harrington et al. (2013) \\
\hline Notophthalmus viridescens & Reilly (1986) & Reilly (1986) & Harrington et al. (2013) \\
\hline Onychodactylus japonicus & & & Harrington et al. (2013) \\
\hline Pleurodeles waltl & & & Harrington et al. (2013) \\
\hline Ranodon sibiricus & & & Harrington et al. (2013) \\
\hline Salamandra salamandra & & & Harrington et al. (2013) \\
\hline Salamandrella keyserlingii & & & Harrington et al. (2013) \\
\hline Siren intermedia & Reilly and Altig (1996) & Reilly and Altig (1996) & Reilly and Altig (1996) \\
\hline \multicolumn{4}{|l|}{ Anura } \\
\hline Alytes obstetricans & & & Yeh (2002) \\
\hline Ascaphus truei & & & Harrington et al. (2013) \\
\hline Anaxyrus boreas & & & Gaudin (1978) \\
\hline Bombina orientalis & & & Harrington et al. (2013) \\
\hline Bufo bufo & & & Harrington et al. (2013) \\
\hline Cornufer guentheri & & & Harrington et al. (2013) \\
\hline Ceratophrys cornuta & & & Harrington et al. (2013) \\
\hline Chacophrys pierotti & & & Harrington et al. (2013) \\
\hline Crinia signifera & & & Harrington et al. (2013) \\
\hline Dendrobates auratus & Sá and Hill (1998) & Sá and Hill (1998) & Harrington et al. (2013) \\
\hline Discoglossus sardus & & & Púgener and Maglia (1997) \\
\hline Epidalea calamita & & & Harrington et al. (2013) \\
\hline Epipedobates tricolor & Sá and Hill (1998) & Sá and Hill (1998) & Harrington et al. (2013) \\
\hline Fejervarya cancrivora & & & Harrington et al. (2013) \\
\hline Hamptophryne boliviana & & & Harrington et al. (2013) \\
\hline Hyla versicolor & & & Harrington et al. (2013) \\
\hline Hylorina sylvatica & & & Harrington et al. (2013) \\
\hline Hymenochirus boettgeri & & & Sá and Swart (1999) \\
\hline Hypsiboas lanciformis & Sá (1988) & Sá (1988) & Sá (1988) \\
\hline Kassina senegalensis & & & Harrington et al. (2013) \\
\hline Leptodactylus chaquensis & & & Harrington et al. (2013) \\
\hline Osteopilus septentrionalis & & & Trueb (1966) \\
\hline Palaeobatrachus sp. & & & Harrington et al. (2013) \\
\hline Pelobates cultripes & & & Harrington et al. (2013) \\
\hline Philautus silus & & & Harrington et al. (2013) \\
\hline Phyllomedusa vaillanti & & & Harrington et al. (2013) \\
\hline Pipa myersi & & & Yeh (2002) \\
\hline Pipa pipa & & Trueb et al. (2000) & Harrington et al. (2013) \\
\hline Pseudacris regilla & & & Harrington et al. (2013) \\
\hline Pseudacris triseriata & & & Harrington et al. (2013) \\
\hline Pseudis platensis & & & Harrington et al. (2013) \\
\hline Pseudophryne bibronii & & & Harrington et al. (2013) \\
\hline Pyxicephalus adspersus & & & Harrington et al. (2013) \\
\hline Rana (Amerana) aurora & & & Harrington et al. (2013) \\
\hline Rana (Amerana) cascadae & & & Harrington et al. (2013) \\
\hline Rana (Amerana) pretiosa & & & Harrington et al. (2013) \\
\hline Rana (Amerana) temporaria & & & Harrington et al. (2013) \\
\hline
\end{tabular}

Continued on next page. 
bioRxiv preprint first posted online Jun. 20, 2018; doi: http://dx.doi.org/10.1101/352609. The copyright holder for this preprint

(which was not peer-reviewed) is the author/funder, who has granted bioRxiv a license to display the preprint in perpetuity.

All rights reserved. No reuse allowed without permission.

Continued from previous page.

\begin{tabular}{|c|c|c|c|}
\hline \multirow[t]{2}{*}{ Taxa } & \multicolumn{3}{|c|}{ Standardization method (data type used) } \\
\hline & Ontogenetic stages & Snout-vent length $(\mathrm{mm})$ & Ossification sequence position \\
\hline Rana (Pantherana) pipiens & & & Kemp and Hoyt (1969) \\
\hline Rhinophrynus dorsalis & & & Harrington et al. (2013) \\
\hline Shomronella jordanica & & & Harrington et al. (2013) \\
\hline Smilisca baudini & & & Harrington et al. (2013) \\
\hline Spea multiplicata & & & Harrington et al. (2013) \\
\hline Triprion petasatus & & & Harrington et al. (2013) \\
\hline Uperoleia laevigata & & & Harrington et al. (2013) \\
\hline Xenopus laevis & & & Harrington et al. (2013) \\
\hline Triprion petasatus & & & Harrington et al. (2013) \\
\hline Uperoleia laevigata & & & Harrington et al. (2013) \\
\hline Xenopus laevis & & & Harrington et al. (2013) \\
\hline \multicolumn{4}{|l|}{ Mammalia } \\
\hline Bradypus variegatus & & & Hautier et al. (2011) \\
\hline Cavia porcellus & & & Hautier et al. (2013) \\
\hline Choloepus didactylus & & & Hautier et al. (2011) \\
\hline Cryptotis parva & & & Koyabu et al. (2011) \\
\hline Cyclopes didactylus & & & Hautier et al. (2011) \\
\hline Dasypus novemcinctus & & & Hautier et al. (2011) \\
\hline Dasyurus viverrinus & & & Hautier et al. (2013) \\
\hline Didelphis albuventris & & Oliveira et al. (1998) & Oliveira et al. (1998) \\
\hline Echinops telfairi & & & Werneburg et al. (2013) \\
\hline Elephantulus rozeti & & & Hautier et al. (2013) \\
\hline Eremitalpa granti & & & Hautier et al. (2013) \\
\hline Erinaceus amurensis & & & Koyabu et al. (2011) \\
\hline Heterohyrax brucei & & & Hautier et al. (2013) \\
\hline Loxodonta africana & & & Hautier et al. (2012) \\
\hline Macropus eugenii & & & Hautier et al. (2013) \\
\hline Macroscelides proboscideus & & & Hautier et al. (2013) \\
\hline Manis javanica & & & Hautier et al. (2013) \\
\hline Meriones unguiculatus & & Yukawa et al. (1999) & Yukawa et al. (1999) \\
\hline Mesocricetus auratus & & & Hautier et al. (2013) \\
\hline Mogera wogura & & & Koyabu et al. (2011) \\
\hline Monodelphis domestica & & & Hautier et al. (2013) \\
\hline Mus musculus & & & Hautier et al. (2013) \\
\hline Ornithorhynchus anatinus & & & Weisbecker (2011) \\
\hline Orycteropus afer & & & Hautier et al. (2013) \\
\hline Perameles nasuta & & & Hautier et al. (2013) \\
\hline Peromyscus melanophrys & & & Hautier et al. (2013) \\
\hline Procavia capensis & & & Hautier et al. (2013) \\
\hline Rattus norvegicus & & & Hautier et al. (2013) \\
\hline Rhabdomys pumilio & & & Hautier et al. (2013) \\
\hline Rousettus amplexicaudatus & & & Hautier et al. (2013) \\
\hline Sus scrofa & & & Hautier et al. (2013) \\
\hline Trachyglossus aculeatus & & & Weisbecker (2011) \\
\hline Talpa spp. & & & Sánchez-Villagra et al. (2008) \\
\hline Tenrec ecaudatus & & & Werneburg et al. (2013) \\
\hline Tamandua tetradactyla & & & Hautier et al. (2011) \\
\hline Tarsius spectrum & & & Hautier et al. (2013) \\
\hline Trichosurus vulpecula & Weisbecker et al. (2008) & & Hautier et al. (2013) \\
\hline Tupaia javanica & & & Hautier et al. (2013) \\
\hline
\end{tabular}

Continued on next page. 
bioRxiv preprint first posted online Jun. 20, 2018; doi: http://dx.doi.org/10.1101/352609. The copyright holder for this preprint

(which was not peer-reviewed) is the author/funder, who has granted bioRxiv a license to display the preprint in perpetuity.

All rights reserved. No reuse allowed without permission.

Lissamphibian origin and ossification sequences

Continued from previous page.

\begin{tabular}{|c|c|c|c|}
\hline \multirow[t]{2}{*}{ Taxa } & \multicolumn{3}{|c|}{ Standardization method (data type used) } \\
\hline & Ontogenetic stages & Snout-vent length (mm) & Ossification sequence position \\
\hline \multicolumn{4}{|l|}{ Squamata } \\
\hline Zootoca vivipara & & & Hautier et al. (2013) \\
\hline Lerista bougainvillii & & Hugi et al. (2012) & Hugi et al. (2012) \\
\hline Liopholis whitii & & Hugi et al. (2012) & Hugi et al. (2012) \\
\hline Hemiergis peronii & & Hugi et al. (2012) & Hugi et al. (2012) \\
\hline Saiphos equalis & & Hugi et al. (2012) & Hugi et al. (2012) \\
\hline \multicolumn{4}{|l|}{ Crocodylia } \\
\hline Alligator mississipiensis & Rieppel (1993a) & & Rieppel (1993a) \\
\hline \multicolumn{4}{|l|}{ Aves } \\
\hline Anas platyrhynchos & & & Maxwell et al. (2010) \\
\hline Cairina moschata & & & Maxwell et al. (2010) \\
\hline Coturnix coturnix & & & Maxwell et al. (2010) \\
\hline Coturnix coturnix (N\&T) & & & Maxwell et al. (2010) \\
\hline Dromaius novaehollandiae & & & Maxwell et al. (2010) \\
\hline Dromaius novaehollandiae (YPM) & & & Maxwell et al. (2010) \\
\hline Gallus gallus & & & Maxwell et al. (2010) \\
\hline Gallus gallus (S\&W) & & & Maxwell et al. (2010) \\
\hline Larus argentatus & & & Maxwell et al. (2010) \\
\hline Larus canus & & & Maxwell et al. (2010) \\
\hline Larus ridibundus & & & Maxwell et al. (2010) \\
\hline Meleagris gallopavo & & & Maxwell et al. (2010) \\
\hline Phalacrocorax auritus & & & Maxwell et al. (2010) \\
\hline Somateria mollissima & & & Maxwell et al. (2010) \\
\hline Stercorarius skua & & & Maxwell et al. (2010) \\
\hline Sterna hirundo & & & Maxwell et al. (2010) \\
\hline Struthio camelus & & & Maxwell et al. (2010) \\
\hline \multicolumn{4}{|l|}{ Testudines } \\
\hline Apalone spinifera & & & Sánchez-Villagra et al. (2008) \\
\hline Chelydra serpentina & Rieppel (1993b) & Rieppel (1990) and Rieppel (1993b) & Rieppel (1993b) \\
\hline Macrochelys temminckii & & & Sánchez-Villagra et al. (2008) \\
\hline Pelodiscus sinensis & & & Sánchez-Villagra et al. (2008) \\
\hline
\end{tabular}

\section{Appendix references}

Adriaens D and Verraes W (1998). Ontogeny of the osteocranium in the African catfish, Clarias gariepinus Burchell (1822) (Siluriformes: Clariidae): Ossification sequence as a response to functional demands. Journal of Morphology 235, 183-237. DOI: 10.1002 / (SICI ) 1097 - 4687(199803 ) $235: 3<183$ :: AID JMOR2>3.0.CO;2-8.

Boy JA (1995). Über die Micromelerpetontidae (Amphibia: Temnospondyli). 1. Morphologie und Paläoökologie des Micromelerpeton credneri (Unter-Perm; SW-Deutschland). Paläontologische Zeitschrift 69, 429457. DoI: $10.1007 /$ BF02987805.

Cote S, Carroll R, Cloutier R, and Bar-Sagi L (2002). Vertebral development in the Devonian sarcopterygian fish Eusthenopteron foordi and the polarity of vertebral evolution in non-amniote tetrapods. Journal of Vertebrate Paleontology 22, 487-502. DoI: 10.1671/0272-4634(2002)022[0487:VDITDS]2.0.CO;2. 
Cubbage CC and Mabee PM (1996). Development of the cranium and paired fins in the zebrafish Danio rerio (Ostariophysi, Cyprinidae). Journal of Morphology 229, 121-160. DOI: 10.1002 / (SICI) 1097 4687(199608)229:2<121::AID-JMOR1>3.0.CO;2-4.

Ehmcke J and Clemen G (2000). The structure and development of the skull of Costa Rican plethodontid salamanders (Amphibia: Urodela). Annals of Anatomy 182, 537-547. DoI: 10.1016/S0940-9602(00) 80100-4.

Gaudin AJ (1978). The sequence of cranial ossification in the California toad, Bufo boreas (Amphibia, Anura, Bufonidae). Journal of Herpetology, 309-318.

Grande L and Bemis WE (1998). A comprehensive phylogenetic study of amiid fishes (Amiidae) based on comparative skeletal anatomy. An empirical search for interconnected patterns of natural history. Journal of Vertebrate Paleontology 18 (suppl. 1: Memoir 4), 1-696. DOI: 10.1080/02724634.1998. 10011114.

Harrington SM, Harrison LB, and Sheil CA (2013). Ossification sequence heterochrony among amphibians. Evolution \& Development 15, 344-364. DoI: 10.1111/ede.12043.

Hautier L, Bennett NC, Viljoen H, Howard L, Milinkovitch MC, Tzika AC, Goswami A, and Asher RJ (2013). Patterns of ossification in southern versus northern placental mammals. Evolution 67, 1994-2010. DOI: 10.1111/evo.12071.

Hautier L, Stansfield FJ, Allen WRT, and Asher RJ (2012). Skeletal development in the African elephant and ossification timing in placental mammals. Proceedings of the Royal Society B: Biological Sciences 279 2188-2195. DOI: 10.1098/rspb.2011.2481.

Hautier L, Weisbecker V, Goswami A, Knight F, Kardjilov N, and Asher RJ (2011). Skeletal ossification and sequence heterochrony in xenarthran evolution. Evolution \& Development 13, 460-476. DOI: 10.1111/j.1525-142X.2011.00503.x.

Hugi J, Hutchinson MN, Koyabu D, and Sánchez-Villagra MR (2012). Heterochronic shifts in the ossification sequences of surface- and subsurface-dwelling skinks are correlated with the degree of limb reduction. Zoology 115, 188-198. Dol: 10.1016/j.zool.2011.10.003.

Kemp NE and Hoyt JA (1969). Sequence of ossification in the skeleton of growing and metamorphosing tadpoles of Rana pipiens. Journal of Morphology 129, 415-443.

Koyabu D, Endo H, Mitgutsch C, Suwa G, Catania KC, Zollikofer CP, Oda Si, Koyasu K, Ando M, and SánchezVillagra MR (2011). Heterochrony and developmental modularity of cranial osteogenesis in lipotyphlan mammals. EvoDevo 2, 21. DoI: 10.1186/2041-9139-2-21.

Langille RM and Hall BK (1987). Development of the head skeleton of the Japanese medaka, Oryzias latipes (Teleostei). Journal of Morphology 193, 135-158.

Laurin M and Germain D (2011). Developmental characters in phylogenetic inference and their absolute timing information. Systematic Biology 60, 630-644. Dol: 10.1093/sysbio/syr024.

Leblanc J and Cloutier R (2005). Developmental modularity and saltatory ontogeny in the Late Devonian osteolepiform Eusthenopteron foordi. In: Leblanc J. Précisions sur l'anatomie de l'ostéolépiforme Eusthenopteron foordi du Dévonien supérieur de Miguasha, Québec. Rimouski, Quebec, Canada: Mémoire de maîtrise (MSc thesis), Université du Québec, pp. 32-84. eprint: http://semaphore.uqar.ca/id/eprint/ 283.

Lillich R and Schoch R (2007). Finally grown up-The significance of adult Micromelerpeton. Journal of Vertebrate Paleontology 27, 106A

Lohmann U and Sachs S (2001). Observations on the postcranial morphology, ontogeny and palaeobiology of Sclerocephalus haeuseri (Amphibia: Actinodontidae) from the Lower Permian of Southwest Germany. Memoirs of the Queensland Museum 46, 771-781. 
Maxwell EE, Harrison LB, and Larsson HC (2010). Assessing the phylogenetic utility of sequence heterochrony: evolution of avian ossification sequences as a case study. Zoology 113, 57-66. DOI: 10.1016/j.zool.2009.06.002.

Müller H (2006). Ontogeny of the skull, lower jaw, and hyobranchial skeleton of Hypogeophis rostratus (Amphibia: Gymnophiona: Caeciliidae) revisited. Journal of Morphology 267, 968-986. DOI: 10.1002/ jmor.10454.

Müller H, Oommen OV, and Bartsch P (2005). Skeletal development of the direct-developing caecilian Gegeneophis ramaswamii (Amphibia: Gymnophiona: Caeciliidae). Zoomorphology 124, 171-188. DoI: 10.1007/s00435-005-0005-6.

Oliveira CA de, Nogueira JC, and Mahecha GAB (1998). Sequential order of appearance of ossification centers in the opossum Didelphis albiventris (Didelphidae) skeleton during development in the marsupium. Annals of Anatomy 180, 113-121. DoI: 10.1016/S0940-9602(98)80005-8.

Olori JC (2013). Ontogenetic sequence reconstruction and sequence polymorphism in extinct taxa: an example using early tetrapods (Tetrapoda: Lepospondyli). Paleobiology 39, 400-428. DoI: 10.1666/ 12031.

Púgener LA and Maglia AM (1997). Osteology and skeletal development of Discoglossus sardus (Anura: Discoglossidae). Journal of Morphology 233, 267-286. DOI: 10.1002/(SICI)1097-4687(199709)233: 3<267::AID-JMOR6>3.0.CO;2-0.

Reilly SM (1986). Ontogeny of cranial ossification in the eastern newt, Notophthalmus viridescens (Caudata: Salamandridae), and its relationship to metamorphosis and neoteny. Journal of Morphology 188, 315-326. DOI: 10.1002/jmor.1051880306.

Reilly SM (1987). Ontogeny of the hyobranchial apparatus in the salamanders Ambystoma talpoideum (Ambystomatidae) and Notophthalmus viridescens (Salamandridae): The ecological morphology of two neotenic strategies. Journal of Morphology 191, 205-214. DoI: 10.1002/jmor.1051910210.

Reilly SM and Altig R (1996). Cranial ontogeny in Siren intermedia (Caudata: Sirenidae): paedomorphic, metamorphic, and novel patterns of heterochrony. Copeia 1996, 29-41.

Rieppel O (1990). The structure and development of the jaw adductor musculature in the turtle Chelydra serpentina. Zoological Journal of the Linnean Society 98, 27-62. DoI: 10.1111/j.1096-3642.1990.tb01218.x.

Rieppel O (1993a). Studies on skeleton formation in reptiles. V. Patterns of ossification in the skeleton of Alligator mississippiensis Daudin (Reptilia, Crocodylia). Zoological Journal of the Linnean Society 109, 301-325. DOI: 10.1111/j.1096-3642.1993.tb02537.x.

Rieppel O (1993b). Studies on skeleton formation in reptiles: Patterns of ossification in the skeleton of Chelydra serpentina (Reptilia, Testudines). Journal of Zoology 231, 487-509. DOI: 10.1111/j.14697998.1993.tb01933.x.

Sá RO de and Hill S (1998). Chondrocranial anatomy and skeletogenesis in Dendrobates auratus. Journal of Herpetology 32, 205-210.

Sá RO de (1988). Chondrocranium and ossification sequence of Hyla lanciformis. Journal of Morphology 195, 345-355. DOI: 10.1002/jmor.1051950308.

Sá RO de and Swart CC (1999). Development of the suprarostral plate of pipoid frogs. Journal of Morphology 240, 143-153. DOI: 10.1002/(SICI)1097-4687(199905)240:2<143::AID-JMOR5>3.0.CO;2-L.

Sánchez-Villagra MR, Goswami A, Weisbecker V, Mock O, and Kuratani S (2008). Conserved relative timing of cranial ossification patterns in early mammalian evolution. Evolution \& Development 10, 519-530. DOI: 10.1111/j.1525-142X.2008.00267.x.

Schoch RR (2003). Early larval ontogeny of the Permo-Carboniferous temnospondyl Sclerocephalus. Palaeontology 46, 1055-1072. DOI: 10.1111/1475-4983.00333.

Schoch RR (2004). Skeleton formation in the Branchiosauridae: a case study in comparing ontogenetic trajectories. Journal of Vertebrate Paleontology 24, 309-319. DoI: 10.1671/1950. 
bioRxiv preprint first posted online Jun. 20, 2018; doi: http://dx.doi.org/10.1101/352609. The copyright holder for this preprint

(which was not peer-reviewed) is the author/funder, who has granted bioRxiv a license to display the preprint in perpetuity.

All rights reserved. No reuse allowed without permission.

Schoch RR (2009). Evolution of life cycles in early amphibians. Annual Review of Earth and Planetary Sciences 37, 135-162. DOI: 10.1146/annurev.earth.031208.100113.

Schoch RR and Witzmann F (2009). Osteology and relationships of the temnospondyl genus Sclerocephalus. Zoological Journal of the Linnean Society 157, 135-168. Dol: 10.1111/j.1096-3642.2009.00535.x.

Trueb L (1966). Morphology and development of the skull in the frog Hyla septentrionalis. Copeia, 562-573. Trueb L, Púgener LA, and Maglia AM (2000). Ontogeny of the bizarre: an osteological description of Pipa pipa (Anura: Pipidae), with an account of skeletal development in the species. Journal of Morphology 243, 75-104. DOI: 10.1002/(SICI)1097-4687(200001)243:1<75::AID-JMOR4>3.0.CO;2-L.

Wake TA, Wake DB, and Wake MH (1983). The ossification sequence of Aneides lugubris, with comments on heterochrony. Journal of Herpetology 17, 10-22. DOI: 10.2307/1563775.

Weisbecker V (2011). Monotreme ossification sequences and the riddle of mammalian skeletal development. Evolution 65, 1323-1335. DOI: 10.1111/j.1558-5646.2011.01234.x.

Weisbecker V, Goswami A, Wroe S, and Sánchez-Villagra MR (2008). Ossification heterochrony in the therian postcranial skeleton and the marsupial-placental dichotomy. Evolution 62, 2027-2041. DOI: 10.1111/j.1558-5646.2008.00424.x.

Werneburg I, Tzika AC, Hautier L, Asher RJ, Milinkovitch MC, and Sánchez-Villagra MR (2013). Development and embryonic staging in non-model organisms: the case of an afrotherian mammal. Journal of Anatomy 222, 2-18. DOI: 10.1111/j.1469-7580.2012.01509.x.

Werneburg R (2018). Earliest 'nursery ground' of temnospondyl amphibians in the Permian. Semana 32, 3-42.

Wiens JJ (1989). Ontogeny of the skeleton of Spea bombifrons (Anura: Pelobatidae). Journal of Morphology 202, 29-51. DOI: 10.1002/jmor.1052020104.

Witzmann F (2006). Developmental patterns and ossification sequence in the Permo-Carboniferous temnospondyl Archegosaurus decheni (Saar-Nahe Basin, Germany). Journal of Vertebrate Paleontology 26, 7-17. DOI: 10.1671/0272-4634(2006)26[7:DPAOSI]2.0.CO;2.

Witzmann F and Pfretzschner HU (2003). Larval ontogeny of Micromelerpeton credneri (Temnospondyli, Dissorophoidea). Journal of Vertebrate Paleontology 23, 750-768. DoI: 10.1671/3.

Yeh J (2002). The evolution of development: two portraits of skull ossification in pipoid frogs. Evolution 56 , 2484-2498. DOI: 10.1111/j.0014-3820.2002.tb00173.x.

Yukawa M, Hayashi N, Takagi K, and Mochizuki K (1999). The normal development of Mongolian gerbil foetuses and, in particular, the timing and sequence of the appearance of ossification centres. Anatomia, Histologia, Embryologia 28, 319-324. DoI: 10.1046/j.1439-0264.1999.00213.x. 